Article

\title{
Rethinking Anger as a Desire for Payback: A Modified Thomistic View
}

\author{
Jan Rippentrop Schnell * and Diana Fritz Cates \\ Department of Religious Studies, University of Iowa, Iowa City, IA 52242, USA; diana-cates@uiowa.edu \\ * Correspondence: jan-rippentrop@uiowa.edu
}

Received: 23 August 2019; Accepted: 29 October 2019; Published: 7 November 2019

\begin{abstract}
This essay takes a fresh approach to a traditional Western philosophical account of anger, according to which anger is best defined as a desire for payback, namely, a desire to make an offender pay a price, in the currency of unwanted pain, for the pain he caused someone else. The essay focuses more specifically on the work of Thomas Aquinas, whose account of anger is often thought to center on a desire for 'just vengeance.' It analyzes and extends aspects of Aquinas's account that have previously been treated too narrowly. It distinguishes three forms of anger, each of which has important features in common, which justify characterizing it as anger. Only one of these forms involves a desire to make an offender suffer for what he did. Even as this essay argues for articulating different forms of anger, it emphasizes the fluidity of anger's forms, features, and relationships to other emotions. It briefly engages philosophical, psychological, and neuroscientific perspectives while working principally in the domain of religious ethics and moral psychology.
\end{abstract}

Keywords: religious ethics; moral psychology; virtue; emotion; anger; vengeance; payback; equal human dignity; Aquinas

\section{Introduction}

When people talk with others about being angry, and their reasons for being angry, they often take for granted that others know just what they are talking about. They assume that what they mean when using the term anger is basically the same as what others take them to mean, which is the same as what others mean when they use the term. This is often a false assumption, as even a brief survey of recent humanistic and scientific research on emotion reveals. Working definitions of anger vary greatly, even and perhaps especially among philosophers who are in the business of definition. When people do try to clarify what they and their interlocutors mean when they use the same term, they sometimes suppose that their task is to arrive at a definition that best corresponds to the essence of anger or a single objective phenomenon of anger. But there is no such thing. There are only familiar patterns of change in people's minds, bodies, and relationships, which they are taught, within various cultural and historical contexts, by means of different languages, to conceptualize and experience as anger or some cognate. Rather than talking about what anger is, then, it is more productive to talk about how anger is best conceived in a given context and for a given purpose. We outline a way of conceiving anger for the purpose of enabling people, especially in US culture, to gain critical self-understanding and talk more truthfully about a force in human life and society that frequently gives rise to anti-social attitudes and behaviors, and to all sorts of dangerous rationalizations for those attitudes and behaviors, but can in some cases make important contributions to human well-being.

This essay first introduces two recent accounts of anger that reflect some of the definitional diversity that is in play within emotion studies. These accounts provide a context for our own effort, not so much to offer another definition of anger, but to take a fresh approach to a traditional definition-an approach that could, we think, be morally consequential. One of the two accounts introduced presents 
a definition of anger as a desire for payback. The second account brings insights from contemporary neuroscience to bear on scholarly efforts to define the emotions, including anger. The essay then outlines a third way of thinking about anger that has a basis in the scholarship of Thomas Aquinas, most notably his Summa Theologiae (Aquinas 2012).

We work with Aquinas for several reasons. First, his analysis of anger is somewhat familiar to scholars and students of many fields, including philosophical and moral psychology and ethics (King 1999; Miner 2009), moral theology or Christian ethics (Harrison 1981; Harak 1996; Barad 2000; Mattison 2004, 2007; Jaycox 2016), religious ethics (Milhaven 1989; Yearly 1990; Cates 1996, 2009, 2018; Green 2007), psychology (Arnold 1960), and medieval studies (Cels 2014). Our analysis should therefore be of interest to many colleagues. Second, Aquinas's definition of anger is likely to have a familiar ring for other readers, too, partly because of its long history, which stretches back at least to Aristotle, and because of its profound cultural influences, which are visible to this day (Kemp and Strongman 1995). This familiarity provides us with a good reference point. Third, Aquinas's discussion of anger is part of a full-blown theory of the passions or emotions. ${ }^{1}$ His theory of emotion is tied systematically to an ontology, a theological anthropology, a theory of action, and a theory of virtue. Because Aquinas's account of anger is connected in a systematic way to these other analyses, it is possible to use any of the latter to fill in gaps in the former. Above all, we choose to work with Aquinas because his account of anger provides an excellent foundation for the approach that we wish to take in this essay.

In delineating a valuable way of thinking about anger, we begin by explicating Aquinas's view. This essay calls attention to points that are made by him but are neglected by many of his interpreters. It makes explicit much that we regard as implicit in, or at least compatible with, what he says about anger. It brackets some aspects of his thought that reflect the limitations of his social and historical location. It challenges other aspects. It elaborates features that we find especially promising. Our engagement with Aquinas's view could thus be said to take the form of what Richard Rorty calls rational reconstruction, where a scholar seeks, in effect, to have a conversation with a wise historical author about a contemporary or perennial problem, the understanding of which the scholar hopes to advance, anticipating that her chosen author will have important insights to contribute (Rorty 1984). However, no bold line can be drawn between our reconstruction of Aquinas's views and our own constructive work, as our thinking about anger has emerged within the context of extended studies of Aquinas's thought.

Finally, the essay introduces a modified Thomistic view of anger. It delineates three forms of anger, which are not specifically enumerated by Aquinas. The essay's thesis is not that these forms are together sufficient to elucidate the concept of anger today or cover what most people in the US and elsewhere think of as experiences of anger. Rather, the articulation of various forms is meant to open Aquinas's account up to some new and valuable possibilities. One of the forms of anger treated here, which appears to be dominant in Aquinas's account, can helpfully be called payback-anger, as long as a person is careful to specify what she means by payback. We call two additional forms of anger protection-anger and recognition-anger. From an ethical perspective, we show how each of these forms can be experienced in ways that are more or less appropriate; none of them is intrinsically good or bad. As scholars of religious ethics, we treat religion along the way as a factor that can influence what a person thinks and the impressions that she carries about anger and its value, both of which affect her ways of experiencing (and not experiencing) anger.

1 Aquinas's treatise is centrally concerned with passio. In this paper we refer to passiones as emotions, with the understanding that, in humans, emotion refers not only to the act of passively being moved, but also to the possibility of bringing higher-order thought to bear on the sensory perceptions that cause a person to be moved in particular ways. See (Cates 2009, pp. 80-102). 


\section{Discursive Context}

Consider, then, two examples that reveal how disparate definitions of anger can be, and more importantly allow us, briefly, to situate our proposal relative to a larger conversation. In Anger and Forgiveness Martha Nussbaum argues that anger is best defined as a set of thoughts or evaluative judgments (Nussbaum 2001, 2016). Anger includes a judgment that someone has wronged us-or someone or something that is important to us (Nussbaum 2016, p. 18). Anger includes also a judgment that it would be good if the wrongdoer were made to suffer for what he did (Nussbaum 2016, pp. 21-23). ${ }^{2}$ If the offender suffered a painful penalty, or if life were simply to go badly for him, he would get what is coming to him. And so would we. His suffering would satisfy at least some of the debt that he incurred by hurting us. It would to some extent restore what was taken, mend what was broken, or otherwise compensate for our loss. It would rebalance the scale of cosmic justice (Nussbaum 2016, pp. 24-25). Nussbaum recognizes that this way of thinking is common, but she argues that it is nevertheless irrational, and embracing irrational thoughts is contrary to virtue. Yes, people should be held accountable for their actions, and the punishment of offenders can be warranted. But it makes no sense to think that, in being made to suffer, an offender could pay, in the currency of unwanted pain, for the pain he caused someone else (Nussbaum 2016, p. 29). Fantasizing about getting even might make a victim feel better, but it also reveals a troubled mind. In cases where someone judges that a slight committed against her has lowered her social status, it is not necessarily irrational to think that, by publicly demoting the offender, the victim could regain some of her status. However, it is narcissistic and neglectful of morality to worry about one's position on a social ladder. On Nussbaum's view, anger is thus always morally problematic and ought not to be indulged (Nussbaum 2016, pp. 5-6, 28-29). ${ }^{3}$

In The Neuroscience of Emotion, neuroscientists Ralph Adolphs and David Anderson are not concerned to assess the rationality or the morality of particular emotions (Adolphs and Anderson 2018). However, like Nussbaum, they are very interested in the prior philosophical question of what an emotion - any emotion-is, or how it is best defined. They know that, without clarity and uniformity of definition, scientists of emotion cannot adequately communicate, interpret, test, assess, or build on each other's findings. Nor can scientists collaborate effectively with humanists.

Adolphs and Anderson propose that emotions in human and nonhuman animals are best defined as internal functional states (Adolphs and Anderson 2018, pp. 18, 39). In animals that have brains, these states can be described as brain states, understood as "spatially and temporally characteristic patterns of neuronal (electrical) activity ... together with associated changes in brain chemistry (hormones, neuromodulators, and such)" (Adolphs and Anderson 2018, pp. 30-31). However, not all animals have brains, and the authors want not to beg the question of whether having a brain—or a brain of a certain type-is necessary for having an emotion. ${ }^{4}$ Hence, they define emotions functionally-that is, in terms of what they do. An emotion is a persistent neurobiochemical state that is caused by sensory inputs and, in turn, causes measurable behavioral outputs, most notably bodily changes and behaviors that enable an organism to survive in the face of environmental challenges (Adolphs and Anderson 2018, pp. 39, $41,47,52$ ). Although some neuroscientists think that even fruit flies have emotions (Anderson 2016; Hamilton 2019), in this essay we focus on emotions in vertebrate animals, principally humans.

Adolphs and Anderson have little to say explicitly about anger, as this is not their chosen topic. Moreover, as they note, most nonhuman animal studies of emotion to date have been done on fear, rather than on anger. However, other scientists have applied a similar definition of emotion to the case of anger (Blair 2012). Adolphs and Anderson's readers, too, can make such an application. Given

2 Nussbaum counts desire as a form of thought, such that a judgment about the value of payback can be construed also as a desire for payback.

3 For critical reflection on Nussbaum's view in Anger and Forgiveness, see (Jackson 2018; Cates 2018).

4 In addition, the authors aim at a uniform science of emotion that can be practiced with regard to any animal species of choice. 
what the authors say about innate and conditioned defensive emotions and behaviors (Adolphs and Anderson 2018, pp. 178-95), anger could be defined as a persistent brain state that occurs when an animal receives a sensory input that another animal has frustrated or injured it in a way that appears to be unfair or contrary to a familiar pattern of social cooperation. Under certain conditions, this brain state causes additional material changes that enable the animal to resist or overcome the damage. In most animals, anger outputs include a rise in heart rate and blood pressure, an upsurge of certain hormones, such as adrenaline and testosterone (or analogues), and changes in bodily comportment and expression. Collectively, these and other changes, which are orchestrated by the brain, facilitate or partly constitute a fight response that is directed at whatever appears to have caused the harm. A fight response enables a human or nonhuman animal to do things such as defend its territory, protect its loved ones, recover and perhaps advance its social position, or deter future encroachments, all of which can help secure for the animal, a social group, and perhaps an entire species, access to life-sustaining resources (Adolphs and Anderson 2018, pp. 193-95; Collias 1944, pp. 92-95). Anger has survival value insofar as it is adaptive in this way, but it can sometimes be maladaptive (Adolphs and Anderson 2018, pp. 47-49). For example, a man might have persistent high blood pressure and levels of testosterone. If he undergoes frequent bouts of anger, which are characterized by additional surges of testosterone, his risk of heart disease increases (American Physiological Society 2018; Peterson and Harmon-Jones 2012). Again, Adolphs and Anderson are not interested in determining the moral value of anger-the contribution it makes to human flourishing and to the common good. However, even if continued life, health, liberty, and security are considered nonmoral goods, they are generally desirable for humans partly because they make the pursuit of moral excellence possible.

The views of Nussbaum and of Adolphs and Anderson concerning emotion are notably different. ${ }^{5}$ It is possible to put the two accounts into meaningful conversation, for example, by focusing on the material elements and adaptive functions of Nussbaum's evaluative judgments, or by thinking of Nussbaum's emotions in light of what Adolphs and Anderson characterize as feelings, namely, subjective experiences of emotion. But that is not our task here. Rather, we want to situate our interpretations of Aquinas and our own thoughts on anger relative to their accounts. Briefly, relative to Nussbaum we affirm the importance of evaluative judgment to the formation of emotional experience. However, we favor a view that also attends more explicitly to sensory impressions and images, and to the manner in which they cause predominantly sensory ways of being moved in relation to what a person regards as helpful or harmful, friendly or threatening. On a Thomistic view, thoughts exert influences on the flow of emotion mainly via the recruitment of new or altered sensory inputs (Cates 2009).

With respect to anger in humans, we favor an account that recognizes a role, not only for sensory desires, but also for intellectual desires and, more comprehensively, for what Aquinas calls motions of the will or volitions. Volition refers to a mode of tending that is caused substantially by a person's own rational and moral judgments, rather than by sensory inputs. ${ }^{6}$ We agree with Aquinas that volition names, among other things, the (limited) power to choose the course of an occurrent emotion, and to do so for a reason. It includes the power, through moral decision making, to acquire good habits of emotion that affect whether and in what way a given emotion is likely to arise in the future.

Finally, we wish to distinguish three forms of anger, only one of which appears to involve what Nussbaum characterizes as the judgment that it would be good for an offender to suffer payback for the wrongful harm that he caused. Many social justice advocates and organizers, for example, report

5 The difference between these accounts is due, not simply to differences of discipline or interests in different levels of explanation. For example, Jesse Prinz, who identifies as a neurocognitive philosopher, defends a Jamesian theory of emotion close to that of Adolphs and Anderson (Prinz 2004). Moreover, William James was himself both a scientist and a philosopher (James [1890] 1950).

6 Rational can refer to being capable of reasoning, whether that reasoning is, in a given case, sound or unsound. Humans, for example, are characterized as rational beings. The contrary of this sense of rational is non-rational. Rational can refer also to the quality of sound reasoning. Some decisions, for example, are rational, and some are not. Here, the contrary is irrational. Context determines meaning. The same is true of the term moral. 
that they do not typically want, in their anger over injustice, to hurt (or to have others hurt) the people who, in their assessment, help to keep unjust social structures in place. Rather, they want to assert the equal dignity of persons in the face of individuals and organizations that refuse to recognize it. They want also to protect vulnerable and disadvantaged people from further harm, and to impel the formation of a more just society (Schnell, forthcoming). They want all of these things and more with a passion, and they call their passion anger.

Relative to Adolphs and Anderson, we prefer not to use the term emotion to refer to brain states that predictably cause physiological and behavioral outputs that do things to sustain an organism's life and social belonging. This way of conceiving of emotion can be useful for certain purposes. For example, it can facilitate referring to emotions on a scale that extends from those that are experienced as fully conscious feelings to those that are unconscious and therefore not experienced at all, where the latter are simply material forces of which an embodied subject is unaware, but which explain the occurrence of recognizable outputs (Adolphs and Anderson 2018, pp. 305-6). However, we favor using the term emotion to refer to an experience, and to characterize what Adolphs and Anderson refer to as emotion as (something like) the neurobiochemical basis of that experience. Historically, emotion-terms have been used by most humanists and the public, at least in Europe and the US, to talk about conscious experiences (Kemp and Strongman 1995; Boddice 2018).

Also, if emotions are defined as brain states, an implication could be that the feeling of an emotion and every other human experience is also, essentially, a brain state, albeit one that occurs within an organism and is dependent on various material inputs beyond the brain itself. Consciousness and self-consciousness would then amount to brain states. Brains would become the subjects of experience. Brains, rather than persons, would become the moral agents who make decisions and hold each other accountable. Relations between persons would amount to relations between brains. We want to take care not inadvertently to reduce persons to their brains (Drees 2003; Fairlamb 2012).

We seek to outline an account of anger that attends to the dynamic interplay between sensory impressions, sensory ways of being moved, higher-order thoughts, and deliberate self-movement. Such an account provides conceptual and linguistic detail and nuance that can help a person to better identify and articulate experiences that she or others are wont to call anger. Psychological research shows that using a relatively expansive and refined vocabulary to articulate personal and interpersonal experiences correlates strongly with mental, physical, and social health (Kashdan et al. 2015; Tugade et al. 2004). From the perspective of virtue ethics, these aspects of health are important because they can provide a basis for human flourishing, understood as a matter of being well and doing well as a morally capable entity (Aristotle 1985, 1098b21).

Our account affirms that emotional experiences have material elements, many of which are similar in form and function across multiple animal species. Keeping the materiality and the animality of human emotion in mind can help a person to ground her inquiry into anger on some basic facts about how human organisms work (Griffiths 1997). It can help her also to avoid over-intellectualizations of problematic forms of anger, which can lend themselves to rationalization ("I feel an intense impulse to flatten you, but my desire is not to hurt you per se. I simply want to make things better between us"). Moreover, mindfulness of the materiality and the animality of emotion implicitly discourages people from thinking that humans do best to eliminate all anger from their lives. Some forms of anger enable people to be strong and resilient in the face of overwhelming obstacles.

Once again, it is important to keep the potential rationality of emotion in mind, as well—namely, the way in which emotion is partly constituted by judgments (connected to impressions) and can be brought into extended rational consideration by a reflective subject. Attending to the cognitive dimension of emotion helps to clarify similarities and differences between the emotions of humans and of other animals, as well as the significance of emotional conditioning and education, especially among humans. To provide a basis for our account, we turn first to the thought of Aquinas. 


\section{Aquinas on Anger}

Aquinas can be interpreted as arguing, somewhat like Nussbaum, Aristotle, and the Stoics, that anger is best understood as a desire for payback, namely, a desire to make someone suffer as just payment for the suffering she caused us or someone to whom we are attached. At the same time, Aquinas is generally interpreted as arguing, unlike Nussbaum and the Stoics, that this desire can sometimes occur in ways that are reasonable and choice worthy. We are sympathetic to the idea that, while many experiences of payback-anger are plainly self-corruptive and destructive of communal bonds, some such experiences can be worth consenting to, for a time. However, the only way for us to arrive at Aquinas's normative conclusion is to unpack and finesse his definition of anger. ${ }^{7}$

Aquinas defines anger, most simply, as appetitus vindictam, which is usually rendered in English as "a desire for [just] vengeance" (Aquinas 2012, I-II 46.4). In persons, anger is paradigmatically directed toward other members of a community to whom just treatment is owed and from whom just treatment is expected (Aquinas 2012, I-II 46.7). ${ }^{8}$ Anger names a person's response to the perception that someone has slighted her unfairly, treated her as if she were of no account, usually in a way that seems publicly visible (Aquinas 2012, I-II 47.2). Feeling pained by a slight, wanting to remove it, and hoping in this possibility, a person rises up against the offender (insurgit contra) in her imagination, if not also in action (Aquinas 2012, I-II 46.1). She denounces the offender and the offense, mentally if not verbally, and desires vindicta (Aquinas 2012, I-II 46.4 ad 3, 48.2). Aquinas is explicit about the formal content of this desire, saying that "vindicta is wrought by the infliction of a punishment [poenae], and the nature of punishment is that it is contrary to the will, painful, and inflicted for some fault. Consequently, an angry person desires this, that the person whom he is hurting may feel it and be in pain and know that this has happened to him on account of the harm he has done to the other" (Aquinas 2012, I-II 46.6 ad 2). For Aquinas, then, ira est appetitus nocendi alteri sub ratione iusti vindicativi, which is usually translated "anger is the desire to hurt another for the purpose of just vengeance" (Aquinas 2012, I-II 47.1). When vengeance is successfully wrought, satisfaction occurs-both in the sense of payment and in the sense of the avenger's pleasure (Aquinas 2012, I-II 48.1).

On this view, a person's anger can be more or less on target, morally. ${ }^{9}$ The ideal is to be "angry at the right things and towards the right people, and also in the right way, at the right time and for the right length of time" (Aristotle 1985, 1125b31). To the extent that a person has acquired a stable disposition to get anger right, her choice to consent to her anger in a given case can be an expression of virtue. Consenting to anger can also, in some situations, be morally required inasmuch as it provides needed motivation to defend the vulnerable and uphold justice for all. None of this is to deny that, for Aquinas, anger is frequently an expression of vice (Aquinas 2012, II-II 158.2, 6).

Let's take a closer look at Aquinas's account, focusing primarily on some distinguishing features of emotions per se and of anger in particular. Every aspect of his account is worthy of analysis, but we limit ourselves to his views concerning: (1) the sort of interior act or operation that anger comprises, qua passio or emotion, and the way in which this sort of act relates to other interior acts of which humans are generally capable, such as thinking, reasoning, willing, and having sensory impressions;

7 Much of the following analysis has a basis in (Cates 2009), which attends in a more comprehensive and systematic way to Aquinas's analysis of the emotions per se.

8 Much recent research shows that many other social animals exhibit a strong sense of unfairness, also known as inequity aversion, but presumably without possessing a formal concept of justice (de Waal 2009). We want to work with an expansive 'sense' of fairness or unfairness, which is always sensory but can be more or less conceptualized, relative to the idea of justice, by humans.

9 Although Aquinas appears to treat virtue and vice as binaries, his theory of virtue implies that an acquired moral virtue is a habit that is stable, but it is more-or-less perfected in a given individual at a given time. To the extent that a person has acquired a given virtue, she is disposed to undergo appropriate emotions and commit appropriate actions in response to life events. We take it that excess and deficiency are also matters of degree, and that there are often more than two ways of missing the mark in expressing a given virtue. 
(2) the central cause of anger on the part of a human subject; and (3) the goal at which a person aims when she is properly said to be angry.

\subsection{What Sort of Interior Act Is Anger? Appetitus}

As noted above, Aquinas characterizes anger as appetitus vindictam. Appetitus is often translated desire, and this is a fitting choice in some contexts. However, appetitus in the thought of Aquinas can signify much more than desire. It can refer to virtually any sort of tending (tendere/appetendere) of an object in relation to another object (Aquinas 1994, 22.3; Cates 2009). Of most interest to us is the way in which Aquinas articulates several levels of appetitus, which signify multiple dimensions of reality, including the reality of human existence.

First, appetitus can refer to a built-in tending, on the part of every living and nonliving thing to be and to hang together as a certain kind of object with a characteristic set of potentialities, which can be realized by acting and being acted on by countless other objects that together compose a vibrant, interactive universe. To take a modern example, it could refer to the tending of an atom, with a certain number of electrons in its outer valence shell, to unite with other atoms in its environment when doing so completes its shell and thus creates greater stability (in both atoms). On this material level, appetitus refers to a causal force that propels a given entity, described on any scale (from an atom, say, to a planet) to be and to behave in characteristic ways as it interacts with other causal forces. Some of these other forces enable the object to persist, through a continuous flow of change, and some threaten the object's existence or integrity. In the face of threats or damages, appetitus can refer to a force of resistance. Such a force is basic to an entity's power to continue to exist. If a corruptible object "did not have the strength to conquer its contrary, it would be destroyed by it" (Aquinas 1994, 22.1, 25.2).

Second, appetitus can refer more specifically to a principle or force that characterizes the operation of living beings (Aquinas 1994, 22.3). It could refer, for example, to the life force itself as it animates a particular organism. It could refer to an organism's tending toward greater homeostasis when it encounters factors that disrupt its ideal state.

Third, in living beings that are sentient, the term can refer to an experience of tending in one way or another. Appetitus could refer, for example, to an animal's sometimes acute and, at other times, mostly background experience of pleasantly being alive, operating well, and favoring the continuation of life. When an animal's appetitus for life and pleasure is blocked by another animal, in a way that strikes the first animal as unfair, another appetitus often arises to "conquer" that block. The latter form of tending in a sentient being is characterized by Aquinas as anger.

Fourth, in living and sentient beings that are also capable of intellectual activities, appetitus can refer to additional operations and experiences. It can refer to a mode of tending, not only to have sensory experiences in response to sensible objects, but also to make those experiences objects for thought and decision. For example, a person might have a strong desire to make an offender suffer, and she might turn her attention to that desire. This turning would already reflect an intellectual tending or an exercise of volition. Upon reflection, the person might realize that her anger is becoming stronger by the moment, and she might ask herself whether this growing intensity is appropriate to the situation. With reference to local social norms, a moral code, or a religious ideal, she might judge that her anger has become excessive and purposefully set out to remedy the excess. All or most of these activities are possible only by virtue of a human being's intellectual powers.

A person who tends deliberately toward the moderation of her anger might nevertheless struggle with sensory pleasures that continue to surge when she pictures the offender in pain, and she might regret this pleasure on moral grounds. Different levels of tending in persons do not always align with each other, which is part of why it can be helpful to distinguish them, and why the cultivation of virtue is so important. On a Thomistic view, there are virtues that dispose a person to experience emotions in ways that are appropriate to her and to a given situation. But these virtues must be acquired over time, and they are not easy to acquire. Strong and demanding sensory impulses can inhibit the acquisition of virtue. Such impulses can also undermine the imperfect virtues that a person has acquired to that point. 
A central challenge of the moral life is to become a person of moral integrity who has the wherewithal to deal constructively with sensory impulses that are intense, but which a person rightly judges to be unworthy of her consent.

Finally, it can be helpful to think of acquired moral virtue as another form of appetitus. Virtue is not inherent in persons, as other general forms of appetitus are. It is not simply built into our 'nature.' But virtue is made possible by principles that are inherent, including a general tending, on the part of all humans, to make choices in light of what they think (correctly or incorrectly) will bring them and other people whom they value closer to happiness (Aquinas 2012, I-II 58.3, 58.4 ad 3). ${ }^{10}$ Correct choices, made repeatedly, give rise to virtues, and virtues create a kind of 'second nature,' which makes it easier and more pleasant for a person to tend and to act in consistently good ways.

The levels of appetitus to which we refer above correspond, in part, to different sorts of entities with different levels of complexity (natural objects, plants, nonhuman animals, and rational animals). They correspond also to different modes of tending within persons or within the same person. We would emphasize, more than Aquinas does, that the levels to which we refer are simply organizing principles. They can be helpful guides, but they can also be misused, as when some humans regard certain other humans as naturally inferior to them or as mere animals in the great chain of being, or when humans view all other animals as mere objects for their own use. While being aware of such limits, we consider several benefits of thinking about anger qua appetitus and in these multilayered terms.

First, if a person recognizes anger as a common response to what is perceived to be an unfair imposition of an obstacle or infliction of a harm, and she grasps that roughly homologous responses can be described in many existing things, she is less likely to think of anger as being, in principle, an aberration from normal animal operations, an expression of irrationality, or merely a form of "magical thinking" (Nussbaum 2016). Anger in humans is an intelligible experience within an intelligible universe (Aquinas 1994, 22.2; Clarke 2001, p. 199). Regarding anger as intelligible is a key step toward developing an intelligent relationship with it.

Second, taking this broad and layered view of anger helps us to explain that, for Aquinas, anger qua appetitus is best characterized, more specifically, as a motus appetitus sensitivus or a motion of sensory appetitus (Aquinas 2012, I-II 22.3). Anger refers to a form of being moved, which an embodied subject undergoes and ordinarily feels when she perceives, senses, or imagines that a given object has caused her unfair harm. As noted, Aquinas distinguishes sensory tending from intellectual or volitional tending (motus appetitus intellectious). Yet he acknowledges that the two are always entangled because humans are generally in the process of thinking when an emotion is evoked, and they immediately direct their thinking to what appears to have evoked the emotion. Moreover, as more thoughts occur regarding the situation at hand, further self-direction and decision making often take place, for good or for ill, and the original experience continues to be altered (Aquinas 2012, I 80.2).

Following Aquinas's lead, we would say that humans do well not to over-intellectualize the judgments that evoke and form part of the cognitive content of anger. Recent animal studies show that some nonhuman animals make something like the judgments that many people have assumed to be peculiar to humans. For example, Capuchin monkeys have been shown to make judgments regarding the inequity of certain behaviors on the part of researchers. They famously throw temper tantrums when they notice that another monkey, with whom they have completed a common task, is rewarded for his efforts, while they receive nothing or noticeably less (de Waal 2009; Deanne-Drummond 2019).

10 One could argue that what Aquinas calls appetitus (here plural) are simply causal factors that are themselves the cumulative effect of innumerable contingent and coincidental causes and effects, stretching back through the process of evolution and ultimately to the hypothesized origin of the universe in the Big Bang. We would expect Adolphs and Anderson, for example, to take this materialist position. For Aquinas, however, all this determinate tending and ordered interactivity among diverse kinds of embodied forms can be understood and characterized adequately only with reference to a first efficient cause, which accounts for the fact that there is anything at all (including a Big Bang), and a final cause of all that exists, which accounts for the fact that all processes of being, interacting, and interactive becoming operate in potentially intelligible ways (Aquinas 2012, I, 2.3; Clarke 2001, p. 199; Tabaczek 2015). Aquinas refers to the efficient and final cause of creation as God. 
It is difficult to describe this sort of judgment, not being immediately familiar with animal cognition. But it appears to involve, minimally, forming valenced sensory impressions. Some other social animals, too, appear to have an evolved capacity to 'sense' that they have been frustrated or harmed unfairly or contrary to social rules. It is reasonable to hypothesize, accordingly, that humans have a similar, evolved capacity. The judgments that evoke emotions are thus best conceived as cognitive in a broad sense-including intellectual and sensory apprehension and processing. Hence, when a term such as wrongful or unfair is used is used in describing a sensory impression, one needs to think more about 'disturbing behavior that upsets familiar social patterns' than about 'the violation of moral rules.'

Fourth, thinking about anger as a multilayered appetitus helps to make the case that every experience that it makes good sense to call anger exhibits some common features, which operate largely on a sensory level. After examining some different forms of anger that we take to be explicit or implicit in Aquinas's account, and after reflecting on reports of experiences of diverse people, we would say that a basic, common feature of such experiences is a felt impulse, in the wake of a perceived wrongful injury, to rise up against the source of the injury or an obstacle that it has created, and compel it to behave in a way that strikes the person as desirable (Aquinas 2012, I-II 48.2). ${ }^{11}$ 'Wanting to compel' can take a variety of forms, and we want to use the term compel in a broad way to refer to any act by which one applies pressure to effect a change in some object that resists being changed. For example, a person might want, in her anger, to make an offender stop what he is doing or go away, when he has no interest in doing so. She might want to impose a limit on his power to do harm, when he is strongly attached to that power (Aquinas 2012, II-II 108.2; I-II 48.2). She might want to force a change in his mind and heart, when he could not care less. If the object of a person's anger is something more complex, such as a social institution, she might want to pressure 'it' to cease practices that damage vulnerable people's lives, when those practices are entrenched, and no one in particular seems to be responsible for them. ${ }^{12}$

Without some reference to 'compelling,' in addition to 'rising up against' (or without tucking 'compelling' into 'rising up against'), neither Aquinas nor we can adequately account for the 'heat' or the prosecutorial force of anger (Aquinas 2012, I-II 48.2). Cartoons sometimes capture this intensity by turning a character's head into a smokestack that is ready to 'blow its top,' compelling the air around it to recede. Cultural and personal differences are always in play, and there will be differences in degree, but we want to point to mostly sensory experiences that we suspect are extremely common and part of the way in which humans have evolved to protect themselves and others from harm.

Aquinas says that anger involves a surge of power that is directed at repelling a perceived evil (Aquinas 2012, I-II 48.2). He holds that this surge is not in and of itself subject to choice in that most people cannot help but experience it now and then. The surge is therefore not something whose very occurrence makes one liable to moral judgment (Aquinas 2012, I-II 24.1; II-II 158.2 ad 3). Agreeing with Aristotle, Aquinas explains that "we are neither praised nor blamed for our emotions [here, in the case of anger, we think of the basic impulse described above], but he does not exclude their becoming worthy of praise or blame, in so far as they are subordinate to reason [at which point, we would say, anger emerges in a more determinate form]" (Aquinas 2012, I-II, 24.2). The conceptual distinction between a kind of impulse, quite like a reflex, and a more persistent and elaborate experience of emotion for which persons have some responsibility is attractive for moral reasons. Neuroscientific research suggests that the basic impulse probably cannot be eliminated from human life without damaging a healthy brain (Adolphs and Anderson 2018). It is tied to the drive for life. Moreover, it often provides important information that something is wrong. As such, the impulse is something

11 An important task in defining anger is distinguishing it from the surrounding territory-defining it in a way that allows people to express differences in experiences that are associated with additional terms such as sorrow, hatred, and daring.

12 Many people do not experience much difference between anger toward a person or an institution and anger toward non-sentient objects that are easy to personalize, such as a drawer that is stuck or a book that has gone missing right before class. One might want, in anger, to compel the drawer to open and the book to appear immediately. 
that many persons ought often to tolerate long enough for them to become more fully cognizant of its message (ideally, while appreciating that anger easily distorts their thinking about this message). In reflecting on her anger, a responsible and resilient person tries to direct it in ways that avoid known pitfalls. In the process, anger's repertoire increases.

The impulse that we have described counts as a form of appetitus. It seems reasonable to describe it more specifically as a form of desire (desiderium or concupiscentia), which Aquinas defines as a tending toward an object that appears suitable (or a tending away from an object that appears unsuitable), and from which one is currently separated (Aquinas 2012, I-II 23.4). We want to make clear, however, that desire is but one form of appetitus. And not all emotions take the form of desires, as is often implied. On Aquinas's view, persons often tend simply to resonate with an object that they perceived as suitable (which Aquinas calls the emotion of love), feel disturbed by an object that is deemed unsuitable (the emotion of hatred), feel pleased when they achieve an object of desire (the emotion of delight), and feel pained when they encounter something that they would have preferred to avoid (the emotion of sorrow) (Aquinas 2012, I-II 23.4). None of these emotions is well-described as a desire.

A general tending toward or away from what strikes a person as helpful or harmful is made possible by a capacity that Aquinas calls potentia concupiscibilia or concupiscible power. Technically, anger is an expression of an additional capacity, which he calls potentia irascibilia or irascible power. The arousal of anger requires a special power, a spiritedness, to struggle against perceived obstacles (Aquinas 2012, I-II 23.1 ad 1). When a person's desire for something good and pleasant, or her desire to avoid something bad and unpleasant, is frustrated in a way that strikes her as wrong, her original desire is largely displaced by an irascible desire for vindicta. It is vindicta that she now regards as attractive, but which she must face considerable difficulty to attain (Aquinas 2012, I-II 46.3 ad 3). With this caveat in mind, regarding different appetitive powers, we will characterize anger as a desire. Anger names a desire that arises at the intersection of sorrow (over damage done) and hope (in the possibility of vindicta) (Aquinas 2012, I-II 46.1).

Finally, thinking about anger as one of many forms of sensory appetitus that occur in humans, under certain conditions, can provide a person with a kind of topographical map by which to orient herself as she seeks to make conscious differences to her interior life. Consider again the person who judges her own anger to be excessive. She might judge that this excess is due mainly to the fact that her brain is disabled by a diagnosed biochemical disorder that she has recently neglected to treat. In response to this primarily physiological problem, she might take a primarily physiologically tack, which is to resume taking her prescribed medication. A person might instead judge that her anger is excessive mainly because she has begun to love certain pleasures too much, such as the pleasure that attends the fantasy of having her every need met by others. In response to this primarily sensory problem, the person might call up and focus on images of neglect or rejection, or images of a roller-coaster, which cause her to feel disturbed and more cautious about relying too much on others for her basic sense of well-being. Or a person might consider the main cause of her excessive anger to be some mistaken judgments that she has acquired about the content of true happiness. She might engage in extended reflection, ideally in the company of a friend or mentor, about how best to arrive at and cultivate a reasonably stable sense of her own value. ${ }^{13}$ She might do all of these things at much the same time.

To summarize this section, Aquinas's view is that anger is well-regarded as a form of appetitus or, more specifically, a mostly sensory desire. It is helpful to view this desire in relationship to other modes of tending, among various sorts of entities, because taking this view enables a person to discern some of anger's adaptive functions, as well as its general and local logics (Lombardo 2011). Aquinas characterizes anger as a desire for vindicta in the wake of what a person senses/judges to be the infliction

13 The reason why friends and mentors are important to this process is that any distortions of appetitus, the causes of which one seeks to address, can affect the very thinking that one brings to bear on those distortions. 
of an unwarranted harm. Making explicit what is mostly implicit in Aquinas's thought, we have homed in on an impulse to rise up against something and compel it in some way to suit one's own (damaged) interests. Depending on how this impulse is elaborated by thought and further sensory engagement, a person's experience will unfold in one way or another.

\subsection{What Typically Evokes Anger? Parvipensio}

As noted, what typically evokes anger, on Aquinas's view, is a perceived injury (iniuria) (Aquinas 2012, I-II 47.2). Iniuria generally implies not simply an injury, but an unjust one (the Latin for law or the right is ius, and for justice is iustitia). Justice concerns a person's relationships with other persons, and it implies a normative standard of equality among humans (Aquinas 2012, II-II 58.7-8; Porter 2016). Jean Porter argues convincingly that, for Aquinas, human equality implies equality before the law; yet the "ideal of equality ... extends well beyond judicial contexts. Negatively, equality implies that no one can be subject to the private judgments or wishes of another ... " Each person's freedom may permissibly be limited only as necessary and by a relevant authority. Positively, the claims that individuals exercise on one another must be rationally justifiable in terms of cogent, impartial standards of reasonableness or fittingness" (Porter 2016, pp. 124, 116-131). There can be legitimate reasons for honoring an individual's claim to receive more of something than a neighbor receives, but the point is that good reasons for the difference can rightfully be demanded, and reasons generally ought, when demanded, to be provided. Aquinas thinks of the basis of differential treatment as being itself a kind of equality, which he calls "equality of proportion" (Aquinas 2012, II-II 58.11). ${ }^{14}$

What typically evokes anger is not just any injury, but more specifically the perception of an unfair slight (parvipensio) to a person's excellence (excellentia), especially a deliberate and publicly visible one (Aquinas 2012, I-II 47.2). Etymologically, parvipensio means "weighing as little" (Milhaven 1989, p. 129). A slight is a failure to treat a person with the respect or deference that she is due as a person. It is a belittling of her or some property of hers that she regards as an important part of who she is. A slight can take the form of a failure to treat a person in accordance with her presumed social rank, as Nussbaum discusses. However, a broader range of meanings and occasions can be uncovered with reference to the concept of excellentia. Some of these possible meanings are also signaled by Nussbaum, but on her view none of them provides a good reason for being angry.

As we interpret Aquinas, excellentia can signify several things. First, it can signify a person's equal human dignity. For Aquinas, all of creation is a reflection of divine perfection, but humanity is of special value because it is such a striking reflection of the divinity. As rational animals, humans have the potential to engage in thought, reasoning, and responsible decision making, all of which are integral to the exercise of moral agency (Aquinas 2012, I 93.4, 109.2 ad 3; Porter 2016, p. 123). Humans are also capable of knowing and loving God as the first principle of being itself, and as the final end toward which all things tend (consciously, unconsciously, or only materially). Further, humans with faith, hope, and charity are capable of knowing and loving God also as an intimate friend (Aquinas 2012, I-II 91.2, 94.2; II-II 23.1). From a Christian perspective, human dignity is a reflection of the face of God, which is revealed in a definitive way in Christ. In scripture, Jesus is depicted as saying that "Just as you did [a good deed] to the least of these who are members of my family, you did it to me," where an implication is that all humans are beloved children of the same divine parent and, as such, they deserve to be recognized as extraordinary in kind and treated with respect (Attridge 2006, Mt 35:40).

Excellentia can also signify moral virtue that a person has acquired through the deliberate use of her capabilities-virtue that disposes her to act and to be moved in consistently praiseworthy ways (Aquinas 2012, II-II 26.6, 129.1). Individuals are generally due respect for their virtue because virtue is

14 A contemporary example of equality of proportion would be that a program director who is holding an annual conference at a large hotel is assigned a suite while the rest of the planning team members receive double rooms, with the understanding that the director will host gatherings in her suite most afternoons in order for the team to network. 
good in itself, people must sacrifice a lot to acquire it, and the exercise of virtue raises the quality of life for the whole community. Interestingly, Aquinas says that, while a morally fine individual has good reason to become angry with those who slight her moral achievements, she generally become angry less often than she has cause to become because she is secure in her excellence (Aquinas 2012, I-II $47.3 \mathrm{ad}$ 2). No other person, through his own action, can take her virtue away from her. Nevertheless, the failure of others to recognize and publicly approve of the virtue that a person regards as hard-won can be experienced as a dismissal of something of great value that ought never to be taken for granted. People other than the virtuous person herself can also become angry-and, Aquinas would say, appropriately so-when someone whom they regard as a moral exemplar is not duly honored.

Excellentia can also signify a skill, talent, gift, or some other nonmoral, but valuable property that relatively few other people have and are able to contribute to the community (Aquinas 2012, I-II 47.3). Anger, for Aquinas, is sometimes a response to a perceived failure on the part of another person or group to appreciate something that is special about an individual-most notably something that the individual has worked hard or sacrificed much to attain. A related excellentia is a person's lovableness to a particular other person, understood as a property that sets the first person apart from other members of the community and gives her special claim on another's affection. Anger sometimes appears as a response, on the part of an individual, to a perceived failure, on the part of someone who says he loves her, to take her and their relationship seriously (Aquinas 2012, I-II 47.2, 47.3 ad 2; Milhaven 1989, pp. 123-36).

Excellentia can signify these and other goods, where the term goods refers to properties that a person has or thinks she has, for which she believes she deserves respect from other persons, in general, or from someone in particular. All persons deserve basic respect simply for what their humanity makes them capable of being and doing-including persons who have not yet made much use of their capabilities and others who have thus far made bad use of them. A person therefore cannot be mistaken in thinking that she deserves the same respect as every other person for her equal human dignity (Aquinas 2012, I 109.2 ad 3; Porter 2016, pp. 122-23). A person can, however, be mistaken about whether she possesses some other property that entitles her to respect or honor above and beyond what she is due by virtue of her humanity. For example, a person can be wrong in thinking that she is an exceptional artist in cases where standards for good art, in a given culture, are widely discussed. A person can therefore be wrong in thinking that she deserves special opportunities and awards as an artist, and she can be wrong in consenting to anger that arises when she perceives that these opportunities and awards are not forthcoming.

Already we have headed into murky waters, where it is less clear than in the cases of human dignity and virtue what it takes to deserve special regard in a given area of achievement. Are there indeed any agreed upon standards, say, in the United States, for good art? This murkiness becomes all the more apparent when we move decisively into another category of excellentia. For Aquinas, excellentia can refer, not only to an inherent or acquired property, but also to the public recognition of a property that we value and believe we possess (Aquinas 2012, I-II 72.1). This distinction is signaled when he says that "we seek for some kind of excellence from all our goods. Consequently, whatever injury is inflicted on us, insofar as it is derogatory to our excellence seems to savor of a slight" (Aquinas 2012, I-II 47.2). Making a distinction between having a property and being publicly recognized for it is important because it permits the clarification that a person can have an excellent property for which she is not recognized and therefore not duly respected. In addition, she can be respected for a quality that she does not possess; for a property that she possesses, but not to a notable degree; or for a property that does not merit respect. The distinction allows us also to be more explicit about the fact that humans are profoundly social creatures. With regard to human dignity, most people want not only to relish in their dignity; they want also to be acknowledged by others for their dignity, and to have others regard it as an obvious constraint on their behavior. With respect to other goods, such as a talent, many people want not only to have their talent and enjoy its practice but also to display it - that is, to express it and to be appreciated for it by others. 
Excellentia in Aquinas appears often to refer to a position of relatively high social status, authority, and privilege. Here a person's social standing and the public recognition of that standing converge. In explaining what different members of a community are due-or simply in reporting the dominant values of Aristotle's time or his own, Aquinas says that, that "just as the higher a man's position is, the more undeservedly he is despised; so the lower it is, the less reason he has for despising. Thus, a nobleman is angry if he be insulted by a peasant; a wise man, if by a fool; a master, if by a servant" (Aquinas 2012, I-II 47.4). As Porter expresses well, "Western European society in the twelfth and thirteenth centuries was structured by hierarchical relations of all kinds-between husband and wife, between those of free and servile status, between the man or woman of substance and the pauper" (Porter 2016, pp. 121-22). Some of these hierarchical relations are still in evidence today in various institutional contexts. Yet some hierarchies that once seemed obviously justifiable to most of the men who benefitted from them, are now widely recognized as illegitimate-as relations of proportional equality for which no good reasons can be supplied.

Arguably, the recognition of certain differentials in social status, authority, and privilege can have important functions in a society. For example, it is widely considered necessary for persons generally to respect their political leaders and to obey the law because communal life is not possible apart from some version of government, a legal system, and successful law enforcement. However, on a Thomistic view, special powers and honors ought generally to be bestowed only on people and institutions that deserve them-especially those that predictably use their 'surplus' in service of the common good (Aquinas 2012, II-II 63.1) Aquinas might not have been fully attuned to the ways in which some people and institutions unjustly claim a disproportionate amount of social or political power and authority on the basis of irrelevant attributes and then use that power in ways that systematically demean and injure whole classes of people, rather than promoting human well-being. We do want readers to be cognizant of this problem, which has implications for anger.

Consider a contemporary example of a white man in the US who believes that he and other white people deserve to control the distribution of social benefits and burdens in 'their country,' and that they deserve more benefits and fewer burdens than black and brown people do because white people's lighter skin color and their 'race' embody natural and cultural superiority. A white man might think that he has good reasons to be angry, say, when a black man seeks to become President of the United States. But it is irrational to think that whiteness as such or being of the 'white race' entitles a person to uneven distributions of public resources-or entitles him to dominate people who look different from him. We believe that, if Aquinas were alive in the US today, he would agree that a white person in the US has no good reason to become angry over a black man's virtuous exercise of social and political power. Moreover, a black man and other people who appreciate him can have good reasons for anger toward racist people-for their groundless presumption of racial and cultural superiority, and for social practices that uphold white supremacy (Aquinas 2012, II-II 42.2 ad 3). In any case, this is our own view.

With regard to high social status and, we would press, privileged access to social power, there are often cultural rules for specifying who is, and who is not, allowed to feel or express anger. This dynamic is extremely problematic, and it deserves extended treatment of its own. Here, we want simply to argue that, while the desire for attention on the part of a privileged person might often be narcissistic, the desire for attention and affirmation on the part of underprivileged persons is another matter. For people today who regularly receive recognition for their excellence and perhaps have a disdain for arrogance, it is important to imagine what it would be like if, from the day they were born, few people affirmed their dignity, gave them meaningful opportunities to excel, or praised them for their accomplishments. We think Aquinas would agree, in principle, that it is reasonable for an oppressed person to want her oppressor to acknowledge that she is a human being with remarkable potential. It is reasonable for her to want more socially dominant people to share with her and other underprivileged people their access to opportunities and rewards. It is reasonable to want certain sorts of public recognition, as these create possibilities to excel in new ways. Accordingly, it is reasonable for 
underprivileged people sometimes to get angry when aware that such recognition is systematically being denied them. The denial of what is due not only makes them feel diminished, but actually does diminish their life chances.

To conclude this section on excellentia or what we will hereafter call excellence, we acknowledge that, like a desire for status recognition, as per Nussbaum, desires to be respected for certain of one's valuable properties and desires to have fair access to social power can also be self-preoccupied and obsessive. They can be out of line in that they tend toward conditions that are themselves unfair. Such desires need to be checked. However, it is important to note that some people are socialized not to appreciate their own worth as persons. Sometimes confident, privileged people exercise their power in ways that effectively convince other persons that, if the most powerful members of their community do not apprehend their valuable properties, they must not have any. As social animals, humans just do come to a sense of their individual and relational identities and value in continual interaction with other humans, and powerful people's attitudes and actions sometimes matter for how vulnerable people fare. This is not to gainsay what many Stoics express so powerfully-that relying on the favorable opinions of others for one's sense of personal and social value can come with considerable costs.

When another person or group blocks one's access to preferred modes of self-realization or social engagement, and a person experiences a desire to rise up against them and force them to recognize her value, it is good to attend to that desire, rather than immediately dismissing it. It is good to dwell for a time on its significance, bringing critical thought to bear on it. ${ }^{15}$ Sometimes anger is warranted, and sometimes it is not. It can be warranted for some people, but not for other people in the same situation. This is not a double standard. Rather, it is a standard of justice that is employed in a way that is context-sensitive and person-relative. The mean in Aristotelian and Thomistic virtue ethics is a relative mean (Aquinas 2012, I-II 64.2 ad 2).

\subsection{What Is the Central Goal of Anger? Vindicta/Vindicatio}

As we have seen, Aquinas defines anger as appetitus vindictam. Vindicta is usually rendered in English as vengeance. Today, the term vengeance can carry different connotations for different people. For example, vengeance can call to mind disturbing sensory images from movies, where a character's joy in life is consumed, first by a terrible wrong that is done to him or someone he loves, and then by his incessant desire to hurt or destroy the person or persons who committed the wrong. Vengeance can call to people's minds the punishment of offenders by a due authority, which they associate with pleasing sensory impressions of order and control. The term can call to mind a pleasurable sensation that some people experience as an upsurge of power in relation to someone whom they want to 'put in his place.' Vengeance can call to mind an inner conflict, where a person is disturbed by the idea that one person would ever deliberately cause another person unnecessary and unwanted pain, but she also thinks that delivering painful punishment for wrongful acts might be necessary for keeping some members of society 'in line' or helping them to reform. And so on.

For Aquinas, vindicta is aligned in meaning with vindicatio, which is the term that he uses in the Summa especially when addressing civil matters, such as the just punishment of people who break the law or fail to provide due payment for services rendered (Aquinas 2012, I-II 87, 108.1). Vindicatio is typically a form of punishment that a due authority or set of authorities carries out in accordance with agreed-upon standards of law and justice (Aquinas 2012, II-II 108.2 ad 3). In other words, it is a social and moral ideal—one that, we would argue, the state often fails to achieve. In light of this ideal, it is possible for a person who has been wrongfully harmed to desire a form of state-imposed vindicatio that she rightly judges to be rational and just. When a victim desires just vindicatio, and it is

15 For a discussion of some of the ambiguities involved in affirming this desire, see (Cates 1996). 
successfully carried out, it is appropriate for her to experience pleasure or satisfaction in relation to this good (Aquinas 2012, I-II 46.2).

Aquinas emphasizes that what the angry victim imagines and enjoys, precisely in her anger, is not the suffering of the offender per se. Taking pleasure in another's suffering, where his suffering is evidently counter to his well-being, is better characterized as an expression of hatred (Aquinas 2012, I-II 46.6). If a victim is properly characterized as angry, then what gives her anticipatory pleasure is the thought of a wrong being righted through the application of vindicatio or, in a more interpersonal context, vindicta (Aquinas 2012, I 108.1). Notably, Aquinas suggests that there is something bad about imposing unwanted suffering on a fellow human being, even if it does appear to serve the end of justice, because human dignity lies, in part, in the power of free will. Forcing someone's will is usually not consistent with respecting his personhood (Aquinas 2012, I-II 46.6; I 48.4-5, 98.8; II-II 108.2; Kilner 2010).

We take Aquinas to say, more precisely, that vindicatio usually refers to a civil act of forcing a painful punishment on an offender because the people who make the laws, the judges who set the punishments, the persons who carry them out, and most of the rest of the community generally agree that this is the only or the best way to amend the wrong that has been done to the victim and also to the community by a serious breach of the order of justice (Aquinas 2012, II-II 108.2). Notably, a person and a community can be wrong in believing that causing an offender pain is the best way to remove the burden of an injury or to mend a breach. They can be wrong in determining how much pain, inflicted in what form of punishment, is required to meet the demands of justice in a given case. When Aquinas says that anger is a desire for 'just' vindicta or vindicatio, he does not imply that what an angered person wants is in fact just. He is saying only that the person's experience is framed by a concern for justice or fairness. There is always a risk, in punishing someone, that a new injustice will be committed in the name of justice, in a way that ironically corrupts the punisher and takes her and the others further away from the possibility of a just society.

Aquinas argues that the officials whose business it is to impose judgment and exact punishment, and every other person who participates in the maintenance of a reasonable social order, ought therefore to cultivate the virtue of vindicatio (Aquinas 2012, II-II 108.2). Aquinas describes this little-discussed virtue as a stable habit that orders the sensory and more specifically the irascible power by which a person desires to rise up against perceived offenses and compel the offender in some way. This habit makes a person prone to respond in an appropriate manner, not only in desire but also in action and in the formation of law and policy. By implication of Aquinas's theory of virtue, the virtue of vindicatio operates in tandem with practical wisdom. A wise person takes all relevant information into consideration before confirming an impression and making an important decision. Today, this information would include empirical findings from the social and psychological sciences, including experimental evidence regarding how humans predictably respond to various forms of punishment under various conditions. Relevant information would also include empirical findings of the way in which the US justice and penal systems operate disparately relative to certain groups of people. Working through such findings is likely to influence the ways in which a person experiences anger toward various offenders.

There might be good reasons for thinking that, in some cases, causing someone pain for the offense he committed is likely to remedy a distorted relationship between him, his victim, and the other members of the community. Aquinas says that punishment properly involves depriving an offender of what he loves most, such as "life, bodily safety, his own freedom, and external goods such as riches, his country and his good name" (Aquinas 2012, II-II 108.3). In causing deprivation, the offender is likely to receive a direct, unforgettable impression of what it feels like to be forced by another person to suffer a serious, unwanted loss (Aquinas 2012, I-II 46.6 ad 2). It feels horrible. To draw out an implication of this point, the hope is that the offender will potentially come to the realization that, if it feels horrible to him, then it also feels horrible to others. And there is no good reason why the offender should think it okay to do something to others that he hates being done to himself. Many humans who badly injure 
others unfairly and on purpose appear to lack empathy. They seldom make an effort to imagine how the world appears and how it is experienced from other people's points of view. Because they do not care to put themselves in others' shoes, many offenders do not grasp that the people they hurt are human subjects of considerable value who feel pain just like they do, and generally abhor it, just like they do. Aquinas's implicit argument is that forcing a person to suffer a painful loss can disturb his self-centered world and thereby compel him to become more conscious of others $a$ fellow persons. The goal can be to impose a visceral experience of common humanity, vulnerability, and interdependency.

It is important to observe that, for Aquinas, anger often takes the form of a desire for just action on the part of the state in defense of oneself or another victim of unjust harm. We suspect that, today, anger is conceived more often as a desire to hurt someone personally or to see his life go badly for a perceived wrong that he committed against us. Let's bridge, then, to the interpersonal context that is likely signified by the term vindicta. Giles Milhaven captures quite well, from a Thomistic perspective, what an angry subject of a slight can desire in her anger. [I] want to make you suffer as you made me suffer or others I love". I want to "bring you back down into an equality with [me and the other people you injured], an equality which you destroyed. In making us suffer, you took us lightly, treated us as of little worth. ... We cannot undo the harm you did us, but as we make you suffer, you do in some way, however inadequate, take us seriously". We would say, "but if we make you suffer ... " because when a person experiences fresh anger, the suffering of its target is generally only a projected possibility. In the angry moment, the victim imagines forcing someone to realize that "you are like the rest of us: you, too, want to be taken seriously for your worth" (Milhaven 1989, p. 141).

Milhaven argues that if anger is expressed as an act of payback it can, in some cases, give both the victim and the offender the experience of being alike in being treated badly, which can possibly forge a bond that is ironically humanizing (Milhaven 1989, pp. 145-51). It can cause a shared suffering of their frailty as human creatures. Personal revenge can also be a way of treating someone as a person, rather than as a nonhuman animal or an object that is not worth a person's time and energy (Milhaven 1989, p. 151). After all, another alternative would be to treat the offender as a mere thing that neither is owed justice, nor owes justice to anyone else. Milhaven's argument is that, if the act of payback can sometimes accomplish or constitute an important moral good, then the desire for payback can sometimes be justified.

Such desires to cause another person harm are frequently out of proportion to the harms that were previously done, and they can be wrong in other ways as well. We would argue that it is partly the loose interplay between the discourse of civil (institutional) contexts relative to a purported ideal of justice and the demands of interpersonal contexts that can lead a person to justify, in her own mind, a personal desire to crush someone with the ready assumption that he 'deserves' it, or with the ready defense that 'justice' requires it. A person might be right about what justice requires in response to a personal offense; but this rectitude cannot simply be implied with reference to judicial or penal standards. We hypothesize that, at least today and in the US, these standards are rarely what a person has in mind in the angry moment. A person ought to be aware of the real object of her desire and the source of her motivation for action-her goal-in cases where a lot is at stake. Granted, it can be very difficult and may sometimes be impossible for a given person to discern truthfully what she wants. Few people with a conscience may be comfortable admitting that they get pleasure in picturing another person in pain - that a lot of what they call anger might be inflected by sadism.

Crossing back over the bridge to the broader civil context, Aquinas clearly believes, further, that causing an offender pain can have a deterrent effect on him and on the rest of the community, which serves to protect and defend innocent people from additional harm (Aquinas 2012, II-II 108.3). This is an empirical question that has been investigated at length. Deterrence is an attempt to set limits on someone's behavior with the threat that, if he steps beyond those limits, he will suffer for it. We believe that the deeper goal in punishing an offender should be to help him get as close as possible to the point where he does not need external deterrents to act in morally and legally responsible ways. The goal should be to help him change his heart, partly by opening up the possibility of empathy and, what is 
more, compassion (Reeder 1998, 2010). As Aquinas says, the proper goal of punishment is actually to restore the virtue of the offender (Aquinas 2012, I-II 87.2 ad 1). How often, we wonder, is this the explicit or even implied goal of anger toward criminal offenders today?

It could turn out that a particular offender is hardened by punishment, rather than softened. By punishing him, he could simply get the message that the best way to secure what you want in life is through violence. Much will depend on what the punishment is, how it is delivered, and who the offender understands himself to be in a given cultural context. However, it is not unreasonable in our view to hope that, in some cases, punishment can force an offender to confront and become more familiar with his vulnerability, which is a bond that he shares with all other persons. Punishment can subject an offender to a felt loss of power, including the power to carry on as if he were an exception-as if he were not, like everyone else, bound by the same set of rules. In other words, bringing a person who has violated the civil and moral law down to earth through the deliberate infliction of pain (say, the pain of incarceration), has the potential to diminish his inclination to act in ways that alienate him from others, most notably when punishment is combined with other humanizing efforts. It has the potential to restore him, to some extent, to a better and more satisfying level of human functioning (Charis-Carlson 2018).

We take it that anger in either civil or interpersonal contexts today is rarely informed by this level of reflection. Anecdotally, we notice that few people can come up with good reasons for believing that punishing an offender, in either case, will actually accomplish the goals at which they aim. Often, anger is formed more by the adoption of anger-scripts that circulate in the public square and about which people rarely make the effort to think critically (Stewart 2007). Consider, for example, President Trump supporters chanting "send her back!" This script, expressing animosity toward certain immigrants to the US, seems to enable a lot of people to feel pleasantly and powerfully angry with others who appear to slight them by not being enough like them or their own immigrant ancestors, or by "taking" jobs that "belong" to the angered ones (Eltahwy 2019). The more a person follows this sort of script, the more immediately, seamlessly, and uncritically it becomes the way she thinks and uses her imagination whenever she feels that she has been down-ranked by someone she does not like or when she senses that she is losing power by having to share it with others. There are other anger-scripts at work in the US, which are rooted in different narratives and reflect different normative commitments. What we encourage is becoming aware of the script that one generally follows and capable of subjecting it to honest critique in dialogue with other people who follow the same or a different script.

As we suggested previously, anger is sometimes directed at complex objects, including groups and institutions. Consider, again, the context of racism and the desires that motivate some racists to think and act in ways that corrupt the goodness of their lives and societies. Many white nationalists feel insulted or demeaned by phrases such as "Black Lives Matter" or by images of black Americans claiming rightful access to social goods (Joseph 2016). Notably, following Aristotle, Aquinas says that anger is always directed at individuals. He says that, while a group can be an object of hatred, anger "is always caused by something in particular because it is caused by some action of the one that hurts us; and actions proceed from individuals" (Aquinas 2012, I-II 29.6). By implication, it would seem that a racist person cannot meaningfully be said to be angry at African Americans as a group. On one hand, we think that, in many cases, racism is better characterized as a form of institutionalized hatred, rather than as a form of institutionalized anger. On the other hand, we want to press a Thomistic account to recognize that it is possible to be angry at assemblages that we create in our minds. Indeed, he makes a brief concession to the idea that a person can experience anger toward a complex object inasmuch as she conceives it $a$ s an individual, as when a person is angry with a tyrannical state (Aquinas 2012, I-II 46.7 ad 3). Partly on the basis of this text, we think Aquinas's theory of anger can be extended to account for the possibility of anger that is meaningfully directed toward more than individuals. Aquinas's creative allowance for the possibility of such anger is valuable partly because it exposes the fact that usually, when someone is angry at a whole group of people, she makes generalizations about the group's members. This approach might be tolerable in some contexts, inasmuch as it is necessary 
for the pursuit of just social and political goals, but homogenizing people in ways that occlude relevant differences is always problematic, and one ought to be clear about what one is doing.

There is another feature of Aquinas's account that makes us confident that it can be extended to include anger toward groups. One of his key insights is that, as an emotion, anger is not simply an abstraction, as the reference to a tyrannical state might initially suggest. Rather, anger is always based on and tied to particular perceived slights. Shifting perspectives, we would call attention to the fact that many social justice organizers report that their anger toward oppressive institutions and practices arises from and remains grounded in painful sensory impressions of previous injuries caused by those institutions or policies, apart from which they cannot muster and make constructive use of anger's transformative power (Schnell 2019). It is partly this connection to and continual engagement with the sensory and the particular that makes anger an emotion, and not merely an intellectual judgment or a motion of the will.

To signal a wider range of anger's objects, and also to take account of a diversity of anger's more specific goals, we suggest interpreting vindicta and vindicatio, in relevant contexts of Aquinas's thought, as vindication. Although the adjective vindictive can carry the implication of mean-spiritedness, the noun vindication suggests to us more so being cleared or exonerated for something that one was accused of doing, but did not do; being proven upstanding after someone has spread rumors and defamed one's good name; regaining safety following another person's endangerment of one's life or well-being; getting someone to change in ways that appear to be required by law, morality, or religion; or being treated as a person and a valuable member of the community after long being treated like an object or a piece of trash. Vindication might also take the form of making a criminal stand trial and subjecting him to the rule of law in a way that is expected to strengthen the legal system.

To summarize this interpretation of Aquinas on anger, we might have gone beyond what Aquinas intended or would have intended were he with us today. However, we are justified in saying that he regards anger as a predominantly sensory appetitus that is evoked by predominantly sensory images and impressions, which operate, in humans, in close relation to and under the continual impact of other, sometimes-complementary and sometimes-conflicting modes of appetitus, as well as thoughts. Aquinas holds that anger is a response to a perceived slight to one's excellence. Inasmuch as one's sense of being taken seriously is elaborated by thought, excellence can refer to a wide range of things, from one's equal human dignity to one's position as a high church official. Conflation of various kinds can happen, such that we might think that we want to be honored for one thing, for which honor is indeed due, but what we really want is to be honored for something else that is more difficult to justify morally.

We propose keeping the meanings of vindicta and vindicatio-or, from here on out, vindication-open and saying that, on a Thomistic account, anger is well-described as a predominantly sensory desire for vindication in the wake of an injury that strikes a person as unfair and damaging to her life prospects. Desiring vindication might involve wanting an offender to be punished by legal or political authorities. Often, however, it involves simply wanting him to 'wake up' to the damage that he has caused. In either case, the desire can be on target or off, just as punishment itself can be on target or off. Desiring vindication can also involve one person or group wanting to persuade or coerce another to acknowledge something that the first person or group takes to be valuable about themselves and that the other has failed to acknowledge or stubbornly refuses to acknowledge. It can involve wanting to stand up for oneself against the crushing pressure imposed by others, putting up a protective shield, or driving an offender off. It can involve wanting to assert one's equal human dignity and having it be recognized by people or institutions, such that this recognition serves as a check on their behavior. The desire for vindication can take many forms, and its different forms may be subject to different sorts of moral evaluation. We conclude that a person's desire to have an offender undergo unwanted suffering is not necessarily morally bad. Yet it is nonetheless morally troublesome because it can so easily give way to an unexamined desire simply to make another suffer because doing so makes us feel better or relieves frustrations of ours that are not really about him. 


\section{The Colors of Anger}

Translating appetitus vindictam/vindicationem as "a desire for vengeance" does not, in our judgment, do justice to the range and subtlety of Aquinas's thought on anger. It also fails to capture an adequate range of human experiences that many people today would characterize as anger. We want now to build on the foundation we have laid with our limited reconstruction and show how anger can take multiple forms, which are similar enough to warrant calling them all anger, yet different enough to warrant giving each its own label (Aquinas 2012, I-II 23.4).

Aquinas affirms that, in principle, anger can be assigned multiple distinct forms. He notes that Damascene named three species of anger: $\mathrm{fel}$ (bilious anger), minor (simmering, menacing anger), and furor (explosive and punitive anger). Aquinas explains that these species are taken "from those things which give increase to anger. This happens in three ways. First from facility of the movement itself, and [Damascene] calls this kind of anger fel [Greek $\chi 0 \lambda \dot{n}$ or cholos as Aquinas writes] because it is quickly aroused. Second, on the part of the grief that causes anger, and which dwells for some time in the memory; this belongs to mania [Greek $\mu \alpha v i \alpha]$... Third, on the part of that which the angry one seeks, namely, vindicta; and this pertains to furor [Greek kóto $\zeta$ ] which never rests until it is avenged" (Aquinas 2012, I-II 46.8). Aquinas says further that "All those things which give anger some kind of perfection are not altogether accidental to anger; and, consequently, nothing prevents them from causing a certain specific difference of anger" (Aquinas 2012, I-II 46.8 ad 3). Damascene's three species are inadequately principled, on our view; it is likely that Aquinas is mostly trying to make space for a predecessor's ideas. However, we appreciate Aquinas's acknowledgment that anger can have multiple species.

\subsection{Multiple Hues of Anger}

While identifying various forms of anger, we want to emphasize the interactivity and fluidity among them - and between anger and other emotions. To this end, we employ a primary metaphor of a color spectrum [Figure 1], which represents relationships among many hues. Hue specifies color, which is determined by a dominant wavelength of light. Blue is a different hue than orange. Yet even within blues there are multiple hues or shades: cobalt, sky blue, navy, and so on. Analogously, anger differs from joy, on any account. Yet even within anger there are different hues. The definition of hue includes the adjective 'dominant' because, in nature, light that comprises a given color is not monochromatic but is rather a mixture of wavelengths with a primary wavelength having more influence than the others on visual receptor cells. Similarly, people with emotional intelligence can identify a dominant emotion, even as they believe that they are experiencing a few others at the same time or shifting from one to another. A dominant emotion can be understood roughly as the way of being moved that commands most of a person's attention and energy and, in many cases, best explains the way she behaves or, perhaps, pictures herself behaving-if only the behavior in question were possible and permitted.

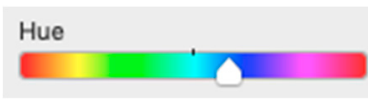

Figure 1. Hue spectrum.

A widely recognized form of anger involves a desire for payback. However, one would not be warranted in assuming that the desire for payback is the central or most definitive form of anger. A group of people could be asked, for example, to pick out the standard color of blue or the bluest blue, among a variety of blues. Many of them would probably pick different hues. A given culture might identify one form of blue as normative, but some of its members might not assent to this judgment. And different cultures might be attached to different blues. Consider the brilliant (sea-colored) blue roofs on buildings in the Greek islands (Shapka 2012) and compare the most common of those hues with the most prominent (sky-colored) hue in Argentina, which is actually called Argentinian blue (Economist Staff 2017). It often makes sense, then, to refer to blues in the plural, and to say that blues comprise a 
wavelength spectrum from $450-495$ nanometers, with 451 being just as blue as 494 . Likewise, anger can take a variety of hues, which could be pointed to on a spectrum, none of which is, in principle, any less anger than the others (Schnell, forthcoming). One could refer to multiple hues of anger as angers in order to disturb the idea that there exist a limited number of discrete forms of anger, some of which define the emotion better than others. However, for our purposes it is simpler to refer to forms of anger, with the understanding that what we are doing is highlighting a few points on a spectrum of possible human experiences, and naming some common and distinguishing features of those experiences.

It is helpful to bring some voices from psychology into perspective. Ira J. Roseman analyzes anger by enumerating the multiple goals and functions that it can have. He refers to the "goals that people want to pursue when experiencing an emotion" as "emotivational goals" (Roseman 2018, p. 148). With reference to other scholars, he specifies that "emotivational goals" can include "[removing] an obstruction (e.g., Frijda 1986; cf. Lench and Levine 2008), correcting some injustice (e.g., Averill 1982), or getting revenge (e.g., Aristotle 1966; Roseman 2011)" (Roseman 2018, p. 148). Within any of these goals a person could potentially specify sub-goals. Referencing the research of Golwitzer et al., Roseman makes the point that a desire for revenge can aim more specifically at "(a) restoring status lost through victimization, and/or (b) obtaining reason to believe the offensive conduct will not be repeated (Gollwitzer et al. 2011)" (Roseman 2018, p. 149).

Anger can have different goals, and thus feel differently, depending also on the person toward whom it is directed. Roseman observes that anger felt toward a loved one, such as a child or a parent, is rarely about revenge. He writes, "although revenge may sometimes be desired in parent-child anger, there are many cases in which it seems to play no part. If a parent is angry at a child for not cleaning his room, or a child at a parent for refusing to allow her to go to a party, the goal seems often to be influencing the target's behavior (and if the behavior changes, anger is likely to diminish)" (Roseman 2018, p. 149). It is in considering anger with respect to intimate relationships that it becomes clearest that "threatening [revenge] may not be integral to the goals of angry persons-making the target act (or not act) in a certain way seems more characteristic across instances" (Roseman 2018, p. 149). That is to say, a more characteristic goals is that of "compelling another" to do or cease doing something (Roseman 2018, p. 150). As we learn from Aquinas, some forms of anger involve a desire to make an offender have a vivid experience of what it is like to have his will, including his free access to what he loves most, painfully constrained. However, there are other modes of wanting, in the face of an obstacle, to bend someone's will or behavior toward our own interests. Part of the 'heat' of anger comes from the resistance to such bending that many persons put up.

In addition to addressing anger's goals, Roseman compiles, from previous research, eight proposed functions of anger Table 1-by functions, he means "correspond[ing] to the likely effect[s] of an emotion strategy in the type of situation which elicits that emotion" (Roseman 2018, p. 152). He calls three of these functions general, and five of them specific (Roseman 2018, pp. 152-53).

Table 1. Functions of Anger.

\begin{tabular}{llll}
\hline \multicolumn{2}{c}{ Relatively General Functions } & \multicolumn{2}{c}{ Relatively Specific Functions } \\
\hline & & 1. & Protect self \\
1. Increase short-term social distance & 2. & Stop transgressions \\
2. Overcome obstacles & 3. & Redress injustice \\
3. Mobilizing resources to address a problem & 4. & Swap subordination for superiority \\
& & 5. & Decrease cooperation, increase imposition \\
\hline
\end{tabular}

It is beneficial, here, to think of anger less as an object, such as a compass, whose needle points in one direction or another and functions to get a person to a desired location, and more as an experience that differs from other, similar experiences, depending on what the experience is centrally about, how it feels in one's body, and what one most desires, in that embodied experience, to do. 
We wish to highlight three hues of anger from a Thomistic perspective that considers the common good in light of historical misuses of power: payback-anger, protection-anger, and recognition-anger. Payback-anger has already been discussed, but let us make explicit what we mean by the term. On our view, payback-anger names a desire to rise up against a perceived offender and, by punishing him (or having someone else punish him), to compel him to pay a price for what he did. Payback-anger refers to a person's desire to exact compensation from someone who caused her or someone else a wrongful injury-a desire that might simply feel like an impulse to pounce on the offender. As with other forms of anger, this desire is predominantly sensory in that it is evoked by sensory impressions and it is mediated by physiological changes. At the same time, even before such a desire arises, discursive thought is taking place, and thought occurs throughout the episode in ways that can be expected to make a difference to how a person feels-hence, the fluid relationship, noted previously, between a basic sense of inequity, which elicits predominantly sensory tending, and an increasingly intellectual judgment that this person has committed a wrong, which elicits a motion of the will geared toward righting the wrong.

Inasmuch as payback refers to the infliction of an evil as fair payment for an unjustified evil that a person inflicted on someone else, it is associated especially with the goal of retaliation, usually grounded in an appeal to lex talionis. Yet the term can suggest, somewhat differently, a person or authority compelling an offender to return to a victim something important that he took from her. The image here is more of a good paid for a good taken, which tends to be associated with the goal of restitution. Granted, there can be evil involved even here in compelling a person to do something that he does not want to do. Payback can signify also a person freely giving to another what she believes the other is due-a kind of reparation, which includes not only the restoration of something taken, but also an offer to repair the relationship itself. Consider an example: A white member of the US community might be prepared to pay something desirable to the African American community for a theft that has long angered its members, including the historical exploitation of their bodies and labor in building a nation, access to whose full benefits many continue to be denied. The white person's desire for reparation might not be motivated by her own anger per se. But it might be motivated by anger that she shares with African Americans, namely, a desire to compel white people to confront the history of racial oppression in the US and to recognize a duty to compensate for the horrors that their forebears inflicted, from which they themselves likely continue to benefit. The goal of this anger might be limited to restitution, but for some people it will also include the creation of new relationships between equals. It can admittedly be difficult to succeed in pressuring someone to make a free offer of civic friendship (Cates 1996).

As noted above, we regard the desire to exact payback from an unwilling offender to be morally problematic inasmuch as it is tied to pleasing images of causing a fellow human being unwanted pain. Even if this desire is also a (more intellectual) desire for justice, and a person is pleased primarily at the possibility of justice, her being pleased with the image of inflicting pain is nonetheless regrettable. Perhaps it would be less regrettable if it were qualified by pain over the very need or the occasion to inflict pain. The desire for vengeance wrought through punishment is problematic partly because of its corrupting effects on the angry person's character. It is all too easy for people who are pleased with another's suffering to become comfortable with the act of inflicting pain or watching it be inflicted, and every day presents opportunities for the expression of dehumanizing callousness. The desire for vengeance wrought through punishment is problematic also because of the likelihood that it will exceed reasonable bounds and, moreover, propel a person or group to act in ways that are unproductive or mostly destructive. As Aquinas notes, a person is not in the best position to determine how much pain it is fair to inflict on an offender when she is already taking pleasure in the thought of that pain (Aquinas 2012, I-II 48.3). This is not to say that a desire for payback that is accompanied by anticipatory pleasure cannot be justified, but only that it needs to be justified before a person could choose well to indulge it. 
In assessing a particular case of such a desire, everything depends (for all agents involved) on the relevant particulars of the case, which can never adequately be specified in the abstract. Nevertheless, an example of a possibly justifiable payback-anger would be a desire to force someone, who appears to many people to care for no one but himself, to become painfully aware that he has done something wrong, and that his behavior will not be tolerated by the community-where an accompanying pleasure, if notable, concerns the restoration of the bonds of community on which everyone relies. This person will not be allowed to make an exception of himself. Payback-anger might, instead, be unjustifiable if, for example, it takes the form of a desire to slam someone down who is already suffering; if our desire is evoked by a minor slight; if it is much too intense for the circumstance and for our own good; if it is never satisfied or it grows inveterate; and so on. Aristotle's apt image of an archer suggests that there are a lot of ways to miss the target completely when it comes to getting emotions right; relatively few ways to hit the target; and even fewer ways to hit the bull's eye (Aristotle 1985, 1094a23).

A second hue of anger worth highlighting is what we call protection-anger. "If someone's hurting my kid, I'm like a momma bear." This familiar simile is born of the human interpretation of a bear's act of rising up to protect her young when threatened, and trying to drive off the threat. Readers can view an example of this behavior in the following YouTube video (https: //www.youtube.com/watch?v=VcQomljKGNA). The mother bear has risen to action, roared her displeasure, and forced the intruding bear to back off. We expect most people to agree that the mother bear is not simply behaving angrily for effect; she desires to drive the other bear off and senses that, if she does not, her cubs will be injured. She does not want in her anger to hurt the other bear per se. Rather, she wants to compel him to leave her and her cubs alone, and she wants to deter him from coming back, sensing that she can best do this by threatening to inflict pain on him. Aquinas may implicitly identify this form of anger when he says that " $[\mathrm{I}] \mathrm{t}$ is natural to everything to rise up against [and repel] things contrary and hurtful" (Aquinas 2012, I-II 46.5, 48.2).

Shifting to the human situation, protection-anger, like other forms of anger, reveals a person's vulnerability to harm. The person is either in imminent danger of a wrongful injury (which already, in a sense, counts as an injury to her security and sense of well-being) or she has been injured directly, and she senses, painfully, that she could be injured again if she does not do something to or against the offender. Many people's desires to rise up against and compel the restraint of an offender's ability to cause harm are not limited to themselves and their loved ones. Many people desire to protect strangers, including imprisoned criminals who, on their view, were wrongfully made extra-vulnerable by a lifetime of social harm and neglect, and are in greater danger than others of further injury. On a Thomistic view, this emotional extension is made via compassion (misericordia), which has a basis in love, where love includes a bond of affection (affectus) that makes it possible for one person to experience another person's good (and also the evil that the other suffers) as partly her own (Aquinas 2012, II-II 30.2; I-II 28.1 ad 2; Cates 1997).

Like payback-anger, protection anger is not inherently good or bad. Again, the details of the circumstances matter, but a potentially justifiable form of such anger would be where a woman is angry at her abusive husband in a way that gives her the strength to leave him - and where her anger does not overly color her imagining and deliberating about how best to accomplish this end. Protection-anger can also take unjustifiable forms, as when a person is frequently, explosively angry and scares other people away in a tragic effort to make himself invulnerable to the sort of hurt that is an unavoidable feature of human love and intimacy. The desire is tragic because the person really does, on some level, want to be loved or at least shown affection.

A third hue of anger worth distinguishing is what we call recognition-anger, which names a person's desire to rise up against another person or group, which refuses to recognize her excellence, and somehow compel that recognition. Tarana Burke describes a teen, named Heaven, who was "filled with anger" at the way she was being treated by another person in her household, and who repeatedly sought Burke out for conversation and counsel. Burke writes, 
Finally, later in the day she caught up with me and almost begged me to listen. I reluctantly conceded, and for the next several minutes this child, Heaven, struggled to tell me about her "stepdaddy" - rather, her mother's boyfriend-who was doing all sorts of monstrous things to her developing body. I was horrified by her words, and the emotions welling inside of me ran the gamut.

I listened until I literally could not take it anymore, which turned out to be less than $5 \mathrm{~min}$. Then, right in the middle of her sharing her pain with me, I cut her off and immediately directed her to another female counselor who could "help her better".

I will never forget the look on her face.

I will never forget the look on her face because it haunts me. I think about her all of the time. The shock of being rejected, the pain of opening a wound only to have it abruptly forced closed again-it was all on her face. As much as I love children, as much as I cared about that child, I could not find the courage that she had found.

As much as I loved her, I could not muster the energy to tell her that I understood, that I connected, that I could feel her pain. I couldn't help her release her shame or impress upon her that nothing that happened to her was her fault. I could not find the strength to say out loud the words that were ringing in my head over and over again as she tried to tell me what she had endured.

I watched her walk away from me as she tried to recapture her secrets and tuck them back into their hiding place. I watched her put her mask back on and go back into the world like she was all alone and I couldn't even bring myself to whisper ... me too (Burke n.d.). ${ }^{16}$

Burke uses two short words to say, 'I see you.' More than that, she says, 'I see you so much, I see myself.' She is brought face to face with her own pain, buried somewhere beneath the "gamut," which is now added to the pain that she already feels for Heaven, and she is awakened to her own anger to match the anger of Heaven. She experiences anger, not only at the fact that both of them have suffered sexual abuse, but also at the realization that countless women, throughout history and around the world have suffered similar abuse-much of it death-dealing. As the woman who initiated the 'me too' movement, Burke invites other women and humane men to awaken to their anger as well. One could say that Burke's anger became partly a desire to create a tidal wave of women-centered power that was strong enough to compel every sexually abusive or enabling man to stand before her, Heaven, and every other woman, and experience the profound moral claim that her humanity makes on them. A person might not be realistic in embracing such a desire. It is very difficult to evoke genuine respect from masses of people who simply do not care about girls and women as persons-especially those who ignore responsible internet media. However, her desire can nonetheless become increasingly rational as she thinks about the way in which a lot of little changes can add up to big changes, if she learns from experience about what works and what does not, and if the ideal outcome that she desires is consistent with the judgment that respect for human dignity is a moral duty and a requirement of virtue.

Recognition-anger can easily overlap with pay-back anger, but it is different in that the person who experiences recognition-anger might not want to cause the other pain in order to exact payment for his wrongful attitudes and behavior. In addition, a person might desire to force an offender to respect her, but not in a way that returns the two of them to a previous status quo. Rather, she might desire to force the other to respect her for the first time, creating a more equitable playing field that has never existed before. Similarly, recognition-anger can easily overlap with protection-anger, but the person who experiences recognition-anger wants more than to drive an offender off, to secure her and others' safety. She wants to enter into a different relationship with her offender. Granted, a person who

\footnotetext{
16 Pink text original.
} 
feels this sort of anger might have been so abused that she hardly knows what being respected feels like; she hardly knows what a better relationship would look like. But she probably 'knows' in her gut, in her anger, that it feels better than constant erasure and degradation.

Like the others, recognition anger can be morally justifiable or unjustifiable. An example of a possibly good form of it would be a surge of self-confidence and power, in a victim, in the form of a desire to grab a misogynistic man by the scruff of the neck and force him, not simply to look at her, but to 'see' her for her excellence (Flescher, forthcoming). As with other examples, the claim is not that acting in the desired way would be morally justified, but only that the desire to act in that way might be justifiable inasmuch as it is a reflection of a person's rightful love for herself and other vulnerable humans. Nor is the claim that a person does well to stoke such anger in order to continue to feel empowered relative to people who shamelessly disrespect her; that would soon become injurious to her, rob her of love and joy in life, and effectively make her the other's slave. The point is simply that such a desire can be reasonable, under certain conditions; what she desires can be something that is good for her, in that moment, and good for the rest of the community.

An example of a more problematic form of recognition-anger would be the desire to force someone to take us seriously, but in a way that we do not deserve to be taken seriously. For example, without being fully aware of it, a person might desire that someone regard her as being at the center of his universe. She might tell herself that she wants simply to be regarded and treated as uniquely special by someone who has expressed his love for her; but a closer look reveals that what she really wants is to be regarded as a god-so that she never has to share her partner's affection with anyone else, and she can maintain the illusion of being safe from the loss of his love. In such a case, the person is probably disposed to become angry whenever her beloved wants to do anything but submit to her narcissistic fantasy and her drive to compel.

In summary of this section, we have identified three forms of anger that are worth being able to distinguish inasmuch as distinguishing them helps a person to refine her ability to identify what she really wants and subject her actual desires to useful moral assessment, as needed. In connection to previous parts of the essay all of these forms have some features in common. They are all responses to perceived, unwarranted slights to some aspect of our excellence-some property of ourselves, or other people in our range of concern, that is important to us. All of these responses involve a desire to rise up against and compel another person's will or behavior, but for somewhat different ends. Pay-back anger names a person's desire to make a perceived offender suffer unwanted pain for the pain he previously caused her. This desire can be elaborated as a desire to impress on him that he will not be allowed to act as though he were above the norms of the group. He will follow the rules or be taken out. Protection-anger names a desire to make someone back off from us or our loved one, get out of our 'face,' and leave us in peace or at least feeling safe from further encroachments on our space from him. And recognition-anger names a desire to make someone acknowledge our equal human dignity or the dignity of others for whom we care. It might extend to include a desire to make someone acknowledge additional qualities that are expressions of our dignity. Note again that, in specifying these three forms, we are not implying that they are the only forms worth identifying. Rather, they should be viewed as a suggestive selection- $\mathrm{a}$ few points on a spectrum. This selection allows us to show that a lot of important experiences, of people in very different social contexts and positions, would be occluded or discounted if the latter two forms of anger were reduced to payback-anger.

\subsection{Fluidity of Anger}

Calling again on the metaphor of the color wheel, multiple blues [Figure 2] can be distinguished for different purposes. For example, a painter might need to make fine distinctions in ordering and mixing his paints. Yet these hues are not actually singular and discrete. Blues occur along continuous spectra that spread incrementally in multiple directions at once. Similarly, although we have specified some different forms of anger, experiences of them should be viewed as porous. Each of them can easily overlap or flow into and out of another as the details of situations change. Each anger-term can 
be a useful construction inasmuch as it allows us to refer to something significant that happens to us, between us and others, and between other people who care about happiness and are disturbed when their path to happiness is thoughtlessly or deliberately blocked. Yet each term can mislead inasmuch as its contingency is not recognized.

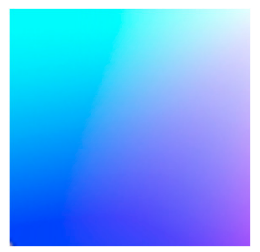

Figure 2. Blue Hues.

When it comes to describing experiences of anger, many people's efforts are limited not only by cultural habits, including anger-scripts, but also by biases, protective defenses, self-deception, physiological makeup, social location, and other factors. Their efforts are conditioned by the ways that they have or have not been encouraged to know themselves and to understand other people's perspectives. Thus, a person's self-descriptions ought not simply to be taken for granted as adequate to the experiences that they are intended to highlight. At the same time, a person's self-descriptions ought not simply to be discounted. Our efforts in this essay are similarly limited, reflective of the experiences of people who have written about anger and spoken of it in their communities-people from whom we have learned and with whose experiences we have sought to identify through the practice of empathy. To acknowledge the contingency of our descriptions does not imply that our scholarly efforts are without merit. It only means that talking about emotions and assessing their roles in human communities is more complex than it might at first appear. One set of nomenclature, one theoretical framework, one branch of moral discourse does not fit all. But the more approaches with which one becomes familiar, the more flexible one can become in being able to home in on certain experiences and assess what is going on 'there.'

Anger moves not only intra-emotionally (among multiple forms of anger), but also inter-emotionally (among emotions) [Figure 3]. Anger is capable of morphing into any number of other emotions. To put it differently, sensory appetitus flows from one form to another in response to the ways in which people register the significance of events. We noted this flow with reference to Aquinas's general theory of emotion. Let's consider a more concrete example here. Consider a religious leader who is made to stand trial before his national religious body for being in a life-long, monogamous same-sex marriage. He is angry, and in his anger he wants at least three things that he can identify. He wants to compel the members of the board, and the church itself, to face up to their discriminatory attitudes and behaviors-to recognize them as unjust. He wants also to compel them to 'get off his case' so he can be safe from their demonstrated power to harm him. And he wants to compel them to 'see' him as a unique person, with many excellences, rather than as a locus of disturbing sexual behavior.

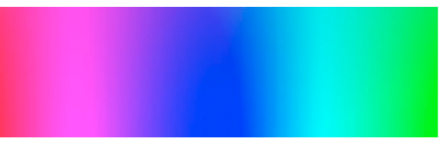

Figure 3. Color Spectrum.

Let's say this man meets with the governing body prior to or at the trial, and its members are gradually convinced by his words, his ethical formation, his model marital love, and his exemplary ministry, that they are in the wrong. Suppose they exonerate him and turn their efforts decisively toward changing church policy. The leader's initial hope that the board would relent, which was part of his original anger, emerges as a hope reflecting the impression that has overcome a big part of the obstacle. Or suppose instead that the man presents his best case, ethically and theologically, and he is publicly supported by other church leaders, textual scholars, and character witnesses from around the 
country. Yet he has the distinct impression that the members of the board are not listening-that they have already made up their minds. They appear to treat him, not as a person, but rather as a negative example and an object lesson for others. The board stays its course, recommends disciplinary action, or revokes his authority. In that case, the leader's anger might be crushed by a stronger power that wants to force him to change, and his anger might give way to sadness or even despair. If his anger persists, the leader might instead withdraw into a cave and think obsessively about what begins to feel more and more like a humiliation carried out by heartless people. His anger might flow into hatred.

It is not only that anger can flow into neighboring emotions; neighboring emotions can also flow into anger. Suppose when the leader is called to stand trial, he is initially sad because he has no hope that the board will recommend a change in rules. But then he is visited by a friend who says "That's just wrong. Present your case! Our religious text supports you. It is their rules that are heretical." His sorrow, linked to hope, emerges now as anger. It is not lost on him that this anger serves as a tie that binds him to his religious community, at least for the time being. Fischer and Roseman (2007) determined that, for their research subjects, anger was more likely to lead to reconciliation than was hatred. Roseman comments that "This finding could be interpreted as indicating that one of the emotivational goals of anger [unlike contempt] is to maintain a relationship with the target of the emotion (e.g., de Vos et al. 2016)" (Roseman 2018, p. 150).

It can be helpful to think of a given experience of anger as part of an emotional suite. Emotions often come bundled together, with each emotion comprising a different angle on one or more scenes or different aspects of the same situation, and each can take a turn, slipping or surging into the more dominant position in a person's awareness. Instead of envisioning a linear flow from one form of anger to another, or to a different emotion altogether, we imagine an undulating force of appetitus that moves irregularly, pushing and pulling in multiple directions, often at the same time. As this image suggests, there is something unstable about emotions that arise, change us, and then recede, giving way to other emotions or relative emotional calm. And yet the instability need not be regarded as a problem. Consider for a moment your skin. It appears intact and stable. Yet in reality it is always sloughing and renewing; human skin completely turns over every few weeks or months depending on a person's age, with the healthiest, most stable skin reconstituting at an express pace. Skin is maximally stable when and because it turns over. Dry, dead, blocked surface cells are shed to accommodate more vital cells rising from deeper layers of skin. By analogy, emotional stability depends on processes of emotional change and renewal, characterized by emergence, possible prominence, death (by way of cessation), turnover, and regeneration. Much of this process simply happens to us, rather than being wrought by us. But it is something of which a mature person can become more aware. A person can practice being at ease with constant interior change in the context of constant exterior change. This being-at-ease in the unfolding of her own reality is characterized by Aquinas as a form of love (amor) (Aquinas 2012, I-II 27.1).

\subsection{Saturation Levels of Anger}

Anger is almost always informed by thought, whether that thought happens to be rational or irrational. Particular episodes of anger are preceded by thoughts about the world, one's situation, one's relationships, and one's nearness to happiness. These thoughts can influence how a situation strikes a person on a sensory level. If a person repeatedly brings sound thinking to bear on emotional aspects of her experience, good habits are likely to develop, which will make it easier for her generally to get anger right, if not in the initial moment of upsurge, then in subsequent moments. Regarding the influence of rational thought and reflection, the color metaphor remains helpful. Color saturation refers to the intensity or purity of a color. A saturation scale shows gradients [Figure 4]. High saturation indicates the most intense form of a given hue, and low saturation or desaturation indicates a less intense form of the same hue. By analogy, a high-saturation anger might be understood as one that is relatively impulsive and opaque, and a low-saturation anger might be understood as one that is more reflective and transparent to its human subject. 


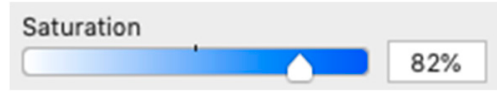

Figure 4. Saturation Spectrum.

Roseman discusses how rational thought can inform behaviors that are expressive of anger. He identifies four points of saturation on a gradient scale: emotionally-governed behavior, emotivationally-governed behavior, motivationally-governed behavior, and cognitively-governed behavior [Figure 5]. On his view, emotionally-governed behavior "is often more impulsive, involving greater reliance on relatively pre-specified patterns of action readiness (e.g., yelling or hitting in anger, freezing or running in fear)" (Roseman 2018, p. 156). These behavioral responses are more preset and have more instantaneous control over behavior than the rest of the spectrum. We can correlate what Roseman refers to as emotionally-governed behavior with the basic experience of anger itself-the impulse to 'rise up against and compel.' Further along the scale, emotivationally-governed behavior is more reasoned than emotionally-governed behavior. It is less impulsive than behavior that is governed by innate tendencies, but more impulsive than behavior that is governed by greater reflection. ${ }^{17}$ Along the same lines, motivationally-governed behavior "is often more deliberative (though much 'deliberation' may occur unconsciously), as executive functions process whether particular responses will result in rewarding or aversive consequences and may compare the relative efficacy of different instrumental actions" (Roseman 2018, p. 156). Again, we can correlate what Roseman refers to as emotivationally and motivationally governed behavior with what happens when an initial impulse becomes overlaid with thought and is conditioned by the further clarification of thought. Roseman only alludes to cognitively-governed (which he calls "non-affective") behavior as a continuation of the spectrum. We would say that, should there come a point on this continuum where a person has lost track of the emotion she previously experienced-if her interior sensory operations give way to a predominance of intellectual activity about the same object-then she is better characterized as acting from a motion of the will, caused mainly by her own thoughts, such that her behavior is mostly the result of choice.

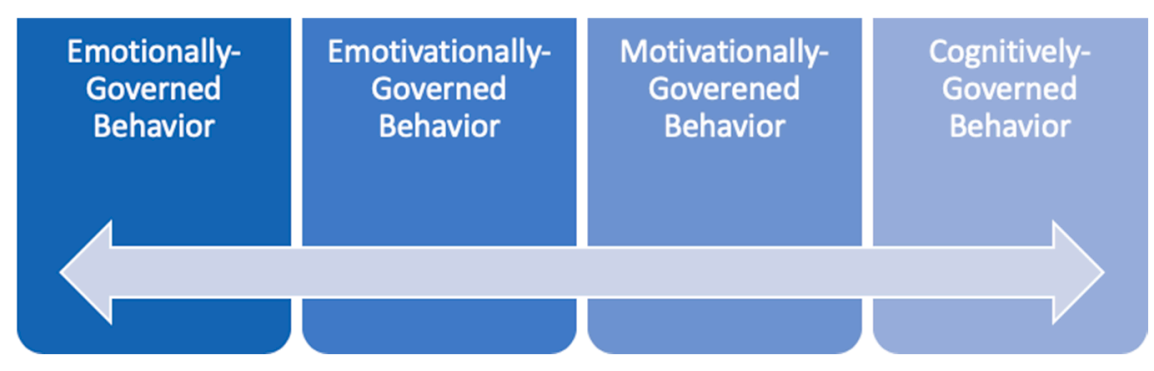

Figure 5. Emotion-Behavior Gradient Scale.

We are concerned in this paper, not with behavioral expressions of anger, but with anger as a form of desire, although it is fascinating to think about the ways in which an agent's action can feed back into the way she feels. Limiting ourselves to three points on a saturation spectrum, we offer somewhat fuller descriptions of various experiences of anger. The first point could represent anger that is most basic, sensory, and immediate-only weakly informed by the self-consciousness and reflection that allow a person to grasp that she is not identical to her anger. If a person reflects on this anger at all, she perhaps has an impression that her anger is driving her.

17 "[B]ehavior governed by emotivational goals may typically have more control precedence than other motivated behavior (because emotivational goals have higher priority or urgency than other goals), but less than behavior governed by emotional action tendencies" (Roseman 2018, p. 156). 
A position midway along the continuum could represent anger that flows into and out of various levels of engagement with a person's intellectual powers. The core impulse is emerging in one or another more determinate form, and the person is aware that she is the subject of her own anger and of much else besides. There is a limited awareness that she can make aspects of her experience objects for thought.

It is interesting to note that, on Roseman's view, the anger-comprising goal of causing an offender pain in order to force him to change-more precisely, the behavior that expresses this desire-lies midway along his saturation spectrum. He writes, "Perhaps harm-seeking should be understood as an intermediate goal of anger-a means to making the target change behavior and deterring similar instances of harm (Fessler 2010)" (Roseman 2018, p. 148). Roseman's comment suggests that, as a person's anger becomes more subject to critical thought, the person is more capable of asking herself what she really or ultimately wants in her anger, and she is better able to work with her desires in light of moral goals.

Toward the end of the spectrum, a person is much more aware of and potentially more truthful about the multiple causes and conditions of her anger. Advanced critical reflection allows a person, under certain circumstances, to become more conscious and discerning about the ways in which her anger is formed by social and cultural conventions and by other influences that comprise so much of the soup within which a human life-form comes to awareness of itself in relationship to other entities. In experiencing a relatively unsaturated form of anger, a person is likely to be aware of herself, not only as a human subject, but also as an agent who is responsible for exercising reason and self-determination with respect to her experience and toward the world within which she is nested. A person is likely to realize that she has the capacity to be a factor influencing the way her life unfolds, even as she experiences the effects of factors over which she has little or no control.

To summarize this section, we have argued that anger can come in multiple hues or shades, not all of which involve a desire to make someone suffer in just payment for committing a wrongful slight. It can be helpful to draw conceptual boundaries between some of these hues for the sake of achieving greater clarity and purchase on aspects of one's emotional life. And yet such boundaries ought to be regarded as porous, and emotions as quite fluid. One form of anger can easily drift into another, and back again, or an agent can deliberately cause an emotional drift as a situation changes and she also changes. Anger can operate as part of a suite of emotions, the members of which engage in frequent interplay. We find it helpful to consider that all emotions are connected as forms of appetitus or tending that orient us in relation to other objects and subjects in our profoundly interconnected and interactive world. Emotion concepts can be thought of as potentially capturing a segment of experience within a sea of appetitive change, which is tied to everything else that is going on in the universe. Finally, anger can arise and persist in forms that are more or less saturated and opaque, more or less unsaturated and transparent to the subject herself.

\section{Conclusions}

We hope to have made several points, some directly and some more indirectly. First, the work of Thomas Aquinas on anger is a rich resource-deeper and more subtle than it is often given credit for. It deserves to be studied and brought into ongoing conversation with contemporary scholarship from intersecting fields, such as philosophy, neuroscience, evolutionary biology, psychology, history, and religious studies. We hope that Aquinas's work continues to be pondered and appreciated in light of questions that really matter to contemporary people, some of which questions appear to be similar to his and some of which are different.

Second, there is much to be said for continuing to think of anger in Thomistic terms as an interior motion-an experience of being moved-which occurs when a person encounters objects of perception that have, or appear to have, a potential influence on her well-being, including the well-being of people whom she regards as part of herself. We think of anger as a predominantly sensory appetitus that is evoked by sensory images and impressions of being unfairly blocked or damaged by someone or some group in our inter-relational, interdependent pursuit of life, liberty, and belonging. It describes 
a often-heated desire to oppose someone whom we perceive to have slighted our excellence and to compel him to do something for us that he probably does not want to do. We have delineated three different forms of anger, each of which embodies a similar impulse, but gets elaborated in different ways. Payback-anger can be described as a desire to make an offender suffer reciprocal frustration or damage or otherwise pay a price for his dastardly deed, anticipating that his suffering will somehow restore to us some of the social power that he wrongfully stripped from us. Protection-anger can be described as a desire to force an offender to stop what he is doing, back off, and leave us alone-at least until he can learn to behave himself. And recognition-anger can be described as a desire to make an offender recognize us for who we are and take us seriously as a subject of equal human dignity who possesses additional excellences as well. In all three of these forms, a person wants to compel another in a way that vindicates her or someone else as a being who deserves to be treated better.

Third, we have sought to make more explicit the fact that a Thomistic approach can and ought to acknowledge the possibility of feeling anger toward groups or institutions. Moreover, it ought to make clear that anger arises in particular cultural settings among people who play different roles and have different sorts of access to social capital, some of it unfair in ways that escape the notice of the people who benefit most from this differential access. We have pressed Aquinas's account to acknowledge that there is nothing natural or necessary about social power hierarchies. Readers should be alert to aspects of any account of anger that appear to ignore, reify, or legitimate unjust social arrangements, disordered relationships, and discriminatory rules for who gets to be angry toward whom.

Fourth, we have made the point that reflecting on anger is important partly because, in thinking about it, we can change it, and by changing it in meaningful ways, we can slowly change our moral character. We can make choices that have the potential to strengthen our relationships to ourselves and to other people. Even though a person's relationship to her own anger can be conditioned by self-deception, defensive rationalization, and other limits, her anger will likely become more reasonable if she is a compassionate and critical thinker who interacts regularly with other compassionate and critical thinkers. How a person thinks about anger not only affects the sorts of anger that she experiences and the ease with which she is able to work with her anger, instead of simply succumbing to it or trying to silence it. Thinking in flexible ways, with reference to specific-enough concepts, also affects the sorts of anger that other people in her life are wont to experience and communicate about, which is part of what constitutes the dynamism of an interactive community of relational beings. ${ }^{18}$

Author Contributions: Conceptualization-J.R.S. and D.F.C.; Writing-original draft, J.R.S. and D.F.C.; Writing-review \& editing, J.R.S. and D.F.C.

Funding: This research received no external funding.

Conflicts of Interest: The authors declare no conflict of interest.

\section{References}

Adolphs, Ralph, and David J. Anderson. 2018. The Neuroscience of Emotion: A New Synthesis. Princeton and Oxford: Princeton University Press.

American Physiological Society. 2018. Hormone Therapy for 'Low T' may not be Safe for all Men: Study finds Testosterone Supplementation raises Blood Pressure in Obese Rats. ScienceDaily. October 3. Available online: https://www.sciencedaily.com/releases/2018/10/181003142925.htm (accessed on 14 June 2019).

Anderson, David J. 2016. Circuit Models linking Internal States and Social Behavior in flies and mice. Nature Reviews Neuroscience 17: 692-704. [CrossRef] [PubMed]

Aquinas, Saint Thomas. 1994. On Truth. Translated by Robert W. Schmidt. Indianapolis: Hackett Publishing, vol. 3. Aquinas, Saint Thomas. 2012. Summa Theologiae. Translated by Laurence Shapcote. Edited by John Mortensen and Enrique Alarcón. Lander: The Aquinas Institute for the Study of Sacred Doctrine.

18 The authors wish to express deep gratitude to three anonymous reviewers whose generous and insightful comments helped to improve this paper a great deal. 
Aristotle. 1985. Nicomachean Ethics. Translated by Terrence Irwin. Indianapolis: Hackett Publishing.

Arnold, Magda B. 1960. Emotion and Personality. New York: Columbia University Press.

Attridge, Harold W. 2006. Harper Collins Study Bible, New Revised Standard Version. San Francisco: Harper Collins Publishers.

Barad, Judith. 2000. Aquinas and the Role of Anger in Social Reform. Logos: A Journal of Catholic Thought and Culture 3: 124-44. [CrossRef]

Blair, Robert James R. 2012. Considering Anger from a Cognitive Neuroscience Perspective. WIREs Cognitive Science 3: 65-74. [CrossRef] [PubMed]

Boddice, Rob. 2018. A History of Emotions. Manchester: Manchester University Press.

Burke, Tarana. n.d. The Inception. Just BE Inc. Available online: https://justbeinc.wixsite.com/justbeinc/the-metoo-movement-cmml (accessed on 2 July 2019).

Cates, Diana Fritz. 1996. Taking Women's Experience Seriously: Thomas Aquinas and Audre Lorde on Anger. In Aquinas and Empowerment: Classical Ethics for Ordinary Lives. Edited by G. Simon Harak. Washington: Georgetown University Press, pp. 47-88.

Cates, Diana Fritz. 1997. Choosing to Feel: Virtue, Friendship and Compassion for Friends. South Bend: University of Notre Dame Press.

Cates, Diana Fritz. 2009. Aquinas on the Emotions: A Religious-Ethical Inquiry. Washington: Georgetown University Press. Cates, Diana Fritz. 2018. You Deserve to Suffer for What you Did. Journal of Religious Ethics 46: 771-82. [CrossRef]

Cels, Marc B. 2014. Interrogating Anger in the New Penitential Literature of the Thirteenth Century. Viator 45: 203-19. [CrossRef]

Charis-Carlson, Jeff. 2018. University of Iowa Brings Higher Education to Prison. Available online: https://www.usnews.com/news/best-states/articles/2018-04-24/university-of-iowa-brings-highereducation-to-prison (accessed on 19 June 2019).

Clarke, W. Norris. 2001. The One and the Many: A Contemporary Thomistic Metaphysics. Notre Dame: University of Notre Dame Press.

Collias, Nicholas E. 1944. Aggressive Behavior among Vertebrate Animals. Physiological Zoology 17: 83-123. [CrossRef] de Waal, Frans. 2009. The Origins of Fairness. New Scientists 204: 34-35. [CrossRef]

Deanne-Drummond, C. E. 2019. Justice, Anger and Wrath: Tracing the Im/Moral Dimensions of Payback. Religions 10: 555. [CrossRef]

Drees, Willem B. 2003. Naturalism. In Encyclopedia of Science and Religion. Edited by J. Wentzel Vrede van Huyssteen. New York: Macmillan Reference USA, vol. 2, pp. 593-97.

Economist Staff. 2017. Two Shades of Blue; Argentine History. Economist 423: 40.

Eltahwy, Mona. 2019. Trump's Attacks on Ilhan Omar Echo His 'Lock Her up' Chants: Here's How They Differ. NBC News. Available online: https://www.nbcnews.com/think/opinion/trump-s-attacks-ilhan-omar-echohis-lock-her-chants-ncna1035701 (accessed on 1 August 2019).

Fairlamb, Horace L. 2012. Breaking the Pax Magisteriorum: The New War of Science and Religion. Symplokē 20: 251-75. [CrossRef]

Fischer, Agneta H., and Ira J. Roseman. 2007. Beat Them or Ban Them: The Characteristics and Social Functions of Anger and Contempt. Journal of Personality and Social Psychology 93: 103-15. [CrossRef] [PubMed]

Flescher, Andrew. Forthcoming. Is There, If Not Virtue, Any Moral Value to Be Found in Payback? Religions.

Green, Keith. 2007. Aquinas on Attachment, Envy, and Hatred in the 'Summa Theologica'. Journal of Religious Ethics 35: 403-28. [CrossRef]

Griffiths, Paul. 1997. What Emotions Really Are: The Problem of Psychological Categories. London: University of Chicago Press.

Hamilton, Jon. 2019. From Fruit Fly to Stink Eye: Searching for Anger's Animal Roots. NPR: All Things Considered. Available online: https:/www.npr.org/sections/health-shots/2019/01/29/688620302/from-fruit-fly-to-stinkeye-searching-for-angers-animal-roots (accessed on 13 June 2019).

Harak, G. Simon, ed. 1996. Aquinas and Empowerment: Classical Ethics for Ordinary Lives. Washington: Georgetown University Press.

Harrison, Beverly Wildung. 1981. The Power of Anger in the Work of Love: Christian Ethics for Women and Other Strangers. Union Seminary Quarterly Review 36: 41-57.

Jackson, Timothy. 2018. Not Far from the Kingdom: Martha Nussbaum on Anger and Forgiveness. Journal of Religious Ethics 46: 749-70. [CrossRef] 
James, William. 1950. The Emotions. In Principles of Psychology. New York: Dover Publications, vol. 2. First published 1890.

Jaycox, Michael. 2016. The Civic Virtues of Social Anger: A Critically Reconstructed Normative Ethic for Public Life. Journal of the Society of Christian Ethics 36: 123-43. [CrossRef]

Joseph, Peniel. 2016. Obama's Effort to Heal Racial Divisions and Uplift Black America. Washington Post. Available online: https://www.washingtonpost.com/graphics/national/obama-legacy/racism-during-presidency.html (accessed on 1 August 2019).

Kashdan, Todd B., Lisa Feldman Barrett, and Patrick E. McKnight. 2015. Unpacking Emotion Differentiation: Transforming Unpleasant Experience by Perceiving Distinctions in Negativity. Current Directions in Psychological Science 24: 10-16. [CrossRef]

Kemp, Simon, and Kenneth T. Strongman. 1995. Anger Theory and Management: A Historical Analysis. The American Journal of Psychology 108: 397-417. [CrossRef]

Kilner, John F. 2010. Humanity in the Image of God. Is the Image Really Damaged? Journal of the Evangelical Society 53: 601-17.

King, Peter. 1999. Aquinas on the Passions. In Aquinas's Moral Theory: Essays in Honor of Norman Kretzmann. Edited by Scott MacDonald and Eleonore Stump. Ithaca: Cornell University Press, pp. 101-32.

Lombardo, Nicholas. 2011. The Logic of Desire. Washington: Catholic University Press of America.

Mattison, William. 2004. Virtuous Anger? From Questions of Vindicatio to the Habituation of Emotion. Journal of the Society of Christian Ethics 14: 159-79. [CrossRef]

Mattison, William. 2007. Jesus' Prohibition of Anger (MT 5:22): The Person/Sin Distinction from Augustine to Aquinas. Theological Studies 68: 839-64. [CrossRef]

Milhaven, J. Giles. 1989. Good Anger. Kansas City: Sheed and Ward.

Miner, Robert. 2009. Thomas Aquinas on the Passions. Cambridge: Cambridge University Press.

Nussbaum, Martha C. 2001. Upheavals of Thought: The Intelligence of Emotions. Cambridge: Cambridge University Press.

Nussbaum, Martha C. 2016. Anger and Forgiveness: Resentment, Generosity, Justice. New York: Oxford University Press.

Peterson, Carly K., and Eddie Harmon-Jones. 2012. Anger and Testosterone: Evidence that Situationally-induced Anger relates to Situationally-Induced Testosterone. Emotion 12: 899-902. [CrossRef] [PubMed]

Porter, Jean. 2016. Justice as a Virtue: A Thomistic Perspective. Grand Rapids: William B. Eerdmans.

Prinz, Jesse. 2004. Gut Reactions: A Perceptual Theory of Emotion. Oxford and New York: Oxford University Press. Reeder, John P., Jr. 1998. Extensive Benevolence. Journal of Religious Ethics 26: 47-70.

Reeder, John P., Jr. 2010. What Kind of Person could be a Torturer? Journal of Religious Ethics 38: 67-92. [CrossRef] Rorty, Richard. 1984. The Historiography of Philosophy: Four Genres. In History in Philosophy. Edited by Richard Rorty. New York: Cambridge University Press, pp. 49-76.

Roseman, Ira J. 2018. Functions of Anger in the Emotion System. In The Function of Emotions: When and Why Emotions Help Us. Edited by Heather C. Lench. New York: Springer, pp. 141-73.

Schnell, Jan Rippentrop. 2019. Anger as Desire. Unpublished Document. University of Iowa.

Schnell, Jan Rippentrop. Forthcoming. Better Living through Anger. Ph.D. Dissertation, University of Iowa, Iowa City, IA, USA.

Shapka, Lindsay. 2012. Greek, White and Blue: Why Are the Buildings in Greece Painted White and Blue? The Anthrotorian. Available online: https:/theanthrotorian.com/history/2012/10/17/greek-white-and-blue (accessed on 11 August 2019).

Stewart, Kathleen. 2007. Ordinary Affects. Durham: Duke University Press.

Tabaczek, Mariusz. 2015. Thomistic Response to the Theory of Evolution: Aquinas on Natural Selection and the Perfection of the Universe. Theology and Science 13: 325-44. [CrossRef]

Tugade, Michele M., Barbara L. Fredrickson, and Lisa Feldman Barrett. 2004. Psychological Resilience and Positive Emotional Granularity: Examining the Benefits of Positive Emotions on Coping and Health. Journal of Personality 72: 1161-90. [CrossRef]

Yearly, Lee H. 1990. Mencius and Aquinas: Theories of Virtue and Conceptions of Courage. New York: SUNY University Press.

(C) 2019 by the authors. Licensee MDPI, Basel, Switzerland. This article is an open access article distributed under the terms and conditions of the Creative Commons Attribution (CC BY) license (http://creativecommons.org/licenses/by/4.0/). 